\title{
Likbez Kampanyası Dönemindeki Propaganda Posterleri Üzerine Göstergebilimsel Bir İnceleme
}

\section{A Semiotic Analysis on Propaganda Posters During Likbez Campaign}

\author{
Caner Çakı", Mehmet Ali Gazi**, Gül Çakı*** ve Ozan Gülada ${ }^{* * * *}$
}

$\ddot{O}_{z}$

1917 yılında gerçekleşen Ekim Devrimi'nden sonra Vladimir Lenin liderliğindeki Bolşevikler Rusya'da iktidarl ele geçirmiştir. Lenin'in yönetiminde ki Rusya'da 26 Aralık 1919 tarihinde "Nüfus Arasinda Cehaletin Ortadan Kaldırlması" (ликвида́чия безгра́мотности у населения) başlı̆̆ında, Likbez (Ликбез) kısa adıyla okuryazarlık kampanyası başlatılmış ve bu kampanyayla birlikte ülkede eğitim düzeyinin yükseltilmesine yönelik yoğun bir çaba sarf edilmiştir. Özellikle kampanya kapsamında kitap okumanın teşvik edilmesine ve kitlelerin okuma alışkanlı̆̆ının gelişmesine yönelik propaganda faaliyetleri gerçekleştirilmiştir. Bu aşamada dönemin önde gelen kitle iletişim araçlarından biri olan propaganda posterlerinden yararlanılmıştır. Çalışmada, Lenin döneminde başlatılan Likbez kampanyasılla kitlelerin kitap okumasının teşvik edilmesi sürecinde propaganda posterlerinden ne şekilde yaralanıldığının ve hangi mesajların verildiğinin ortaya konulması amaçlanmıştır. Bu amaçla çalışmada belirlenen 9 propaganda posteri, Rus dilbilimci Roman Jakobson'un göstergebilim kavramları ışığııda analiz edilmiştir. Çalışmada elde edilen bulgularda kitap okuyan insanların mutlu ve huzurlu bir yaşama sahip olacağına yönelik algıların oluşturulmaya çalışıldı̆̆g, diğer yandan kitap okumanın Komünizm ideolojisiyle yakınlaşmanın bir yolu olarak sunulduğu ortaya çıkarılmıştır.

Anahtar Sözcükler: Okuryazarlık; okuma alışkanlı̆̆l, komünizm; Rusya; Lenin; propaganda.

\begin{abstract}
The Bolsheviks led by Vladimir Lenin seized power in Russia after the October Revolution in 1917. A literacy campaign was launched in Russia under the title of "Elimination of Ignorance Among the Population" (ликвида́ция безгра́мотности у населения), with the short name Likbez (Ликбез) and an intense effort was made to raise the level of education with the campaign in the country under the leadership of Lenin on December 26, 1919. Especially within

\footnotetext{
* Arş. Gör. İnönü Üniversitesi, İletişim Bilimleri ABD. E-posta: caner.caki@inonu.edu.tr Res. Assist. Inonu University, Department of Communication Sciences

** Dr. Öğr. Üyesi, Malatya Turgut Özal Üniversitesi Görsel İletişim Tasarımı Bölümü. E-posta: maligazi@gmail.com

Assist. Prof. Dr., Malatya Turgut Ozal University, Department of Visual Communication Design

*** Doktora Öğrencisi, Maltepe Üniversitesi, Halkla İlişkiler ve Reklamcıllk ABD. E-posta: gulcaki06@hotmail.com

PhD Student, Maltepe University, Public Relations and Advertising Department

***** Öğr. Gör., Malatya Turgut Özal Üniversitesi Akçadağ MYO. E-posta: mehmet.guldada@ ozal.edu.tr

Lecturer, Malatya Turgut Ozal University, Akçadağ Vocational High School
} 
the scope of the campaign, propaganda activities were carried out to encourage reading books and to develop the reading habits of the masses. At this stage, propaganda posters, one of the leading mass media tools of the period, were used. In the study, it was aimed to reveal how the propaganda posters were used and what messages were given in the process of encouraging the masses to read books in Likbez, which was initiated in Lenin's reign. For this purpose, 9 propaganda posters determined were analyzed in the light of the semiotics concepts of the Russian linguist Roman Jakobson. In the findings of the study, it was revealed that the perceptions that people who read books would have a happy and peaceful life were tried to be formed, on the other hand, reading was presented as a way of getting closer to the Communism ideology.

Keywords: Literacy; reading habbit; communism; Russia; Lenin: propaganda.

\section{Giriş}

Rus toplumunda, yetişkin nüfusun okuma yazma bilmemesi 19. yüzyılın sonundan itibaren ciddi bir sosyal sorun olarak ön plana çıkmıştır (Петрова, 2007, s. 519). Bolşevikler, nüfusun kitlesel cehaletini ortadan kaldırma ve halk eğitim sisteminin yeniden düzenlenmesi sorununu son derece önemli bir siyasi görev olarak görmüştür (Лебедева, 2012, s. 776). Ekim Devrimi'nin lideri ve Marksist-Leninist ideolojinin fikirsel önderi olarak kabul edilen Vladimir Lenin, iktidarı döneminde Rusya'da okuryazarlığı arttırmaya yönelik önemli girişimlerde bulunulmuştur. Cehaletin önlenmesine yönelik mücadeleye girişilmiş (Аракелова, 1994, s. 76), en kısa sürede okuma yazmanın kazandırılması amaçlanmıştır (Павлова, 2014, s. 40). Вu aşamada ülkede başlatılan okuryazarlık kampanyasıyla insanlar, okuma yazma öğrenmeye ve beraberinde kitap okumaya teşvik edilmiştir. Kamuoyu üzerinde etki oluşturması amaciyla yararlanılan propaganda yöntemi (Y1lmaz, 2020, s. 542), Lenin'in okuryazarlık kampanyasında kullanılmıştır. Ülkede gerçekleştirilen propaganda faaliyetlerinde insanların okuryazar olmasının önemine vurgu yapılmış, hazırlanan propaganda posterlerinde kitap okuyan insanlar, idealize edilen vatandaşlar olarak kitlelere sunulmuştur. Lenin'in okuryazarlık kampanyası, Rus İç Savaşı'nın (1917-1922) sürdüğü yıllara denk gelmesine karşılık, kampanyaya devam edilmiş ve mümkün olduğunca Rusya'da okuryazar oranının arttırılmasına ve insanların kitap okuma alışkanlığı kazanmasına çalışılmıştır.

Okuryazarlık seferberliğini farklı ülkeler üzerinden inceleyen akademik çalışmalar bulunmaktadır. Bu çalışmalar içerisinde: Lucas (1981), Azab (1985), Irak'1; Mammo (1982), Amare (2006), Etiyopya'yı; Badiane (1983), Senegal'i; Unsicker (1987), Tanzanya'y1; Grainger (1987), Mpofu (1997), Zimbabve'yi; Mujica (1981), Prieto (1981), Leiner (1987), Serra (2001), Herman (2012), Abendroth (2014), Küba'y1; Rao (1999), Soundarapandian (2000), Mohanty (2005), Hindistan'1; Dardour (2000), Erguig (2017), Fas'1; Angus (1980), Hanemann (2006), Nikaragua'yı; Ortega ve Rodríguez (2008), Venezuela'yı; Akinde ve Omolewa (1982), Braimoh (1983), Omolewa (2008), Nijerya'yı ve McKay (2018), Güney Afrika'yı incelemiştir.

Rusya özelinde de okuryazarlık üzerine bazı akademik çalışmalar yapılmıştır. Bu çalışmalar içerisinde: Koutaissoff (1951), okuryazarlık ve SSCB'nin Slav olmayan cumhuriyetlerdeki yerini; Guroff ve Starr (1971), 1890-1914 yılları arasında Rusya'da kent okuryazarlığını; Stevens (1980), Onyedinci yüzyıl Rus ordusunda okuryazarlığı; Mironov 
(1986), 1797-1917 yılları arasında Rusya'da okuryazarlığı; Kraevskii (1987), Sovyetler Birliği'nde yetişkin okuryazarlığını; Eklof (1987), 1861-1939 yılları arasında Rus okuryazarlık kampanyalarını; Nazarova (1988), Sovyet Rusya'da okuryazarlığı öğretme yöntemlerini; Mironov (1991), Rusya ve SSCB'de okuryazarlığın gelişimini; Clark (1995), sendikalar içindeki Rus okuma yazma kampanyasını; Clark (2000), NEP-Dönemi Rusya'daki okuma yazma kampanyasını; Kisel (2008), erken Sovyet Rusya'da okuryazarlık ve edebiyat ustalığını; Golobokova (2011), Rusya'da okuryazarlık ve demokrasiyi; Bradley (2012), St. Petersburg Okuryazarlık Komitesi'ni ve Rus eğitimini; Mažeikienė ve Juraite (2014), Sovyet medyası boyutunda propaganda, eleştirel medya okuryazarlığı ve katılımı; Kefeli (2014), imparatorluk Rusya'sında okuryazarlığı ve Natolochnaya vd. (2018), 1850'li yılların sonu 1860'lı y1lların başında Rus birliklerinde okuryazarlık mücadelesini ele almıştır.

Lenin ve eğitim odaklı gerçekleştirilen akademik çalışmalar da bulunmaktadır. $\mathrm{Bu}$ çalışmalarda: Ravkin (1964), Halk Eğitim Komiserliği'nde Leninist çalışma tarzını; Lilge (1968), eğitim politikasını; Lapko ve Lyusternik (1970), bilim ve eğitimi; Korolev (1970), halk eğitimini; Klarin (1970), halk eğitimi için mücadeleyi ve Zimianin (1985), halk eğitiminin gelişmesine yönelik Leninist ilkeleri incelemiştir. Ayrıca okuryazarlık ve propaganda ilişkisini inceleyen alanda çeşitli akademik çalışmalar da yer almıştır (Paul, 2010; Hobbs ve McGee, 2014; Barrington, 2005; Hobbs vd., 2018; Salma, 2019).

Ulusal literatürde son yıllarda göstergebilim yöntemi kullanılarak çeşitli konular özelinde propaganda posterlerinin incelendiği ortaya çıkmaktadır. Karaca (2018) iş gücü elde etme boyutunda İtalyan Sosyal Cumhuriyeti'ndeki: Arıca (2019), sporun teşvik edilmesi boyutunda Çin Halk Cumhuriyeti'ndeki; Dündar (2019), sporun teşvik edilmesi üzerinden Mussolini İtalya'sındaki; Gülada (2019), İkinci Dünya Savaşı'nda casusluk konulu Sovyetler Birliği'ndeki; Işık ve Karaca (2019), Müttefik Devletleri'ne karşı yürütülen propaganda üzerinden Vichy Fransa'sındaki; Kızılcı ve Kavuran (2019) İkinci Dünya Savaşı'nda Japonya'ya yönelik korku çekiciliği boyutunda ABD'deki; Çalışkan (2020), Stalin'in liderlik kültü inşası boyutunda Azerbaycan Sovyet Sosyalist Cumhuriyeti'ndeki ve Yılmaz vd. (2020), antisemitizm boyutunda Nazi Almanya'sı işgali altında bulunan Sırbistan'daki propaganda posterleri üzerine incelemede bulunmuştur.

Ulusal çalışmalar içerisinde yakın zamanda Jakobson'un göstergebilim yöntemi kullanılarak farklı konularda çalışmaların gerçekleştirildiği de görülebilmektedir. Bu çalışmalar içerisinde: Çakı (2020), insan ticaretinde çocuk istismarı konulu kamu spotu reklamlarını; Çakı ve Gülada (2020), Ermenistan Sovyet Sosyalist Cumhuriyeti'nde Ermeni kadınların propaganda posterlerindeki temsilini; Çalışkan ve Doğan (2020), Sovyetler Birliği'ndeki radyo yayınlarında propaganda amaçlı kullanılan Kutsal Savaş şarkısını; Şahan (2020), Sovyetler Birliği'nde Batı Blok'unun radyo yayınlarını konu alan karikatürleri ve Yılmaz (2020), İkinci Dünya Savaşı'nda Japon medyasındaki Tokyo Rose radyo yayınlarını Jakobson'un modeli özelinde incelemiştir.

Ulusal literatürde doğrudan kütüphane ve kitaplar özelinde de göstergebilimsel çalışmaların yapıldığı ortaya çıkmaktadır. Bu çalışmalar içerisinde: Aladağ (2019), "Kütüphane Haftası" konulu afişlerini; Gazi vd. (2020), Çin Halk Cumhuriyeti'nde gerçekleşen Çin Kültür Devrimi'nde okuma alışkanlığı boyutunda propaganda posterlerini ve Keskin Yılmaz vd. 
(2020), Nazi Almanya'sında antisemitist propaganda boyutunda Zehirli Mantar hikaye kitabını göstergebilimsel açıdan ele almıştır.

Çalışmada propaganda posterleri özelinde Lenin döneminde başlatılan okuryazarlık kampanyasında kitlelerin kitap okumasının teşvik edilmesine yönelik gerçekleştirilen propaganda faaliyetlerinde hangi mesajların verildiği ve kitlelerin okuma alışkanlığı kazanmasında propagandanın ne yönde kullanıldığı incelenmiştir.

Çalışma kapsamında elde edilen bulgular üzerinden aşağıda yer alan sorulara cevap aranmaktadı;

-Kitlelerin okuma yazma öğrenmesinin teşvik edilmesine yönelik hangi mesajlar verilmektedir?

-Komünizm ideolojisinin kitlelerin okuma alışkanlığı kazanmasındaki rolü nedir?

-Kitap okuyan insanlar posterlerde ne şekilde sunulmaktadır?

-Kitap okumasının teşvik edilmesinde hangi görsel ve yazılı kodlardan yararlanılmaktadır?

Çalışma, Lenin döneminin eğitim politikası hakkında bilgi vermesi, Rusya'da Komünizm ideolojisine ait söylemlerin okuryazarlık kampanyasındaki rolünü ortaya çıkarması, Ekim Devrimi'nden sonra Rusya'daki komünist rejimin kitap okumanın teşvik edilmesine yönelik söylemlerini aktarması bakımından önem taşımaktadır. Çalışmada elde edilen bulgular üzerinden ideolojik söylemlerin okuryazarlık kampanyası ve kitap okumanın teşvik edilmesi üzerinde ne gibi bir rolü olabileceğinin açıklanması amaçlanmıştır.

\section{Lenin Yönetiminde Rusya'da Uygulanan Eğitim Politikasına Genel Bakış}

Bolşevik Parti, 1917 y1lında iktidara geldiğinde Rusya (Wade 2006, s. 72), Birinci Dünya Savaşı'nda İttifak Devletleri'ne karşı İtilaf Devletleri'nin yanında savaşmaktadır. Ülke, savaşta büyük kayıplara uğramış ve yıpranmıştır. Bolşevik Parti lideri Vladimir Lenin, İttifak Devletleri ile 3 Mart 1918 tarihinde Brest-Litovsk Antlaşması'nı imzalayarak Rusya'yı savaştan çekmiştir. Yeni yönetim, eski yönetimin dâhil olduğu tüm uluslararası paktlardan ayrılmış ve uyguladığı siyasetin barıştan yana olduğunu belirtmiştir (Maharramova Cengiz ve Şimşek, 2017, s. 41). Rusya'nın savaştan çekilmesiyle Lenin, enerjisini komünist rejimin ülke geneline hakim olmasına yönelik faaliyetlere odaklamıştır. Bu süreçte pek çok alanda Komünizm ideolojisinin temel alındığı reformlar başlatılmıştır. Lenin tarafından başlatılan reformların yoğun olarak uygulandı̆̆ alanlardan biri de eğitim olmuştur.

Lenin, okuryazarlık oranın düşük olduğu bir yönetim devralmıştır. Bu süreçte Lenin'in uyguladığı eğitim politikasının önceliğinde okuryazarlık eğitimi yer almıştır. Ülkede okul reformu gerçekleşmiş (Ross, 1960, s. 539), uygulanacak eğitim politikasında önce ülkede okuryazar oranının arttırılmasına, ardından kitlelere okuma alışkanlığı kazandırılarak, Komünizm ideolojisinin idealize ettiği eğitimli ve entelektüel bir toplumun inşa edilmesine çalışılmıştır. Ülkede kadın ve erkek arasındaki okuryazarlık oranında kadınların aleyhinde bir dengesizlik söz konusudur. Lenin döneminde uygulanacak eğitim politikasında erkekler kadar kadınlar da ön planda tutulmuş, erkek ve kadın arasındaki okuryazarlık dengesizliğinin ortadan kaldırılmasına yönelik çaba sarf edilmiştir. Bu şekilde Bolşevik Parti, kadınların eğitimi yoluyla, toplumdaki ataerkil egemenliğini kırmayı, kadın ve erkek eşitliğini ön plana çıkarmayı 
hedeflemiştir. Ülkede mutlak iktidarı elinde bulunduran Lenin (Karabulut, 2009, s. 71), kadınların okuryazar olmalarına, eğitim almalarına ve neticede ağır sanayi de dâhil olmak üzere pek çok farklı iş kolunda erkekler gibi ön plana çıkmalarına çalışmıştır. Böylece ülkenin ihtiyaç duyduğu iş gücünde daha fazla kadının istihdam edilmesi planlanmıştır. Lenin'in uyguladığ1 eğitim politikasında, ülkede okuryazarlığın arttırılmasının yanında kitap okunmasının da teşvik edilmesine yönelik çalışmalara yer verilmiştir. Bu aşamada kırsal kesimde ülkenin dört bir yanındaki köylerde okuma odaları inşa edilmiş, inşa edilen okuma odalarına insanların gelmesi teşvik edilmiştir. Okuma odaları, kütüphaneden ziyade bir propaganda merkezi olarak ön plana çıkmış, burada yer alan okuryazar bir köylü, yerel topluluk üyeleriyle parti direktifiyle gönderilen metinler üzerinde tartışmalara liderlik etmiştir. Bolşevik Parti'nin liderliğinde oluşturulan okuma odaları, yerel halkın çeşitli konularda yaşananlardan haber alacağı yerler olmuştur.

\section{Lenin'in Okuryazarlık Kampanyası ve Kitap Okunmasının Teşvik Edilmesi}

Rusya İmparatorluğu'nda nüfusun çoğunluğu okuryazar değildir. Özellikle, az sayıda okulun bulunması nedeniyle kırsal alanlardaki nüfusun okuryazarlık oranı oldukça sınırlı kalmıştır. Cehaletin ortadan kaldırılması, 1917 yılının Ekim ayından sonra hükümetin karşı karşıya kaldığ1 en önemli sorumluluklardan biri olmuştur (Сажина, 2012, s. 12). Lenin, ekonomik ve politik faydalarından kaynaklı olarak okuryazarlık konusuna büyük önem atfetmiştir. $\mathrm{Bu}$ süreçte ülkedeki okuryazarlığın arttırılması amacıyla Lenin tarafından çeşitli çalışmalar başlatılmıştır. Bu çalışmalar kapsamında 26 Aralık 1919 tarihinde "Nüfus Arasında Cehaletin Ortadan Kaldırılması” (ликвида́ция безгра́мотности у населения) başlığında, “Likbez” (Ликбез) kısa adıyla okuryazarlık kampanyası hayata geçirilmiştir. Kampanya, Lenin'in kararnameyi imzalamasıyla birlikte başlamıştır. Kararnamenin imzalanmasıyla, yetişkin nüfus için okuma yazma eğitiminin organizasyonu, yetkililerin çalışmalarındaki en önemli konulardan biri haline gelmiştir (Петрова, 2007, s. 519). Bu kararnameye göre 8 ila 50 yaş arasındaki ülkedeki tüm vatandaşların anadillerinde okuryazar olmasının önü açılmış ve insanların okuryazar olmaları doğrudan komünist rejim tarafından desteklenmiştir. Likbez kampanyası kapsamında okuryazarlık eğitimi için on binlerce merkez düzenlenmiş, diğer yandan okuryazarlık eğitimi veren öğretmenlerin yetiştirilmesine de çalışılmıştır. MarksistLeninist felsefeyle yakından ilişki bir eğitim (Zepper, 1965, s. 33), Komünizm ideolojisinin kitlelere benimsetilmesinde önemli bir konu olarak değerlendirilmiştir.

Likbez kampanyası, Rus İç Savaşı'nın sürdüğü bir dönemde başlamıştır. İç savaşta Bolşevik Parti'nin desteğindeki Kızıl Ordu ile Bolşevik Parti’nin muhaliflerinin oluşturduğu Beyaz Ordu arasında kanlı ve şiddetli çarpışmalar yaşanmış; ülke, yaşanan iç savaştan sert bir şekilde etkilenmiştir. İç savaş sürerken Bolşevikler bir yandan okuryazarlık kampanyasını sürdürmüş, bir yandan da Komünizm ideolojisinin kitleler tarafından benimsetilmesine yönelik propaganda yapmıştır. Bolşevikler, iç savaş süresince imparatorluk yanlılarının ve milliyetçilerin ülkeye egemen olmasını önlemeye ve onların ideolojik söylemlerinin toplum tarafından benimsenmesinin önüne geçmeye çalışmıştır. Diğer yandan devrimle gelen siyasi başarıya karşılık, nüfusun önemli bir kısmı devrim ilkelerinin neyi ifade ettiği konusunda bilgiye sahip olmamıştır (Özdemir, 2018, s. 110). Bolşevikler tarafından gerçekleştirilen okuryazarlık kampanyasında Komünizm ideolojisinin doğrudan etkisi ortaya çıkmıştır. 
Okuryazarlık kampanyasında Komünizm ideolojisinin propagandası yapılmış ve Komünizm ideolojisini benimseten ve yücelten kitapların insanlar tarafından okunması teşvik edilmiştir. İnsanların fikirlerini istenilen yönde biçimlendirmeyi amaçlayan propaganda faaliyetlerinde (Avc1, 2018, s. 75-76), kitaplar ön plana çıkmıştır. Bolşevikler tarafından kitaplar, ideolojik söylemlerinin kitleler tarafından benimsenmesinde kullanılan birer propaganda aracı haline getirilmiştir. Neticede komünist eğitimi üzerine Marksist-Leninist öğretim, bilimsel Komünizm teorisiyle bütünsel olarak bağlantılı olmuş ve yeni bir toplum inşa etmek için halk mücadelesine hizmet etmiştir (Monoszon, 1981, s. 35).

Devrimden sonra, Halk Ĕ̌itim Komiserliği (Народный комиссариат просвещения) okullara siyasi propaganda yapma amaciyla bilinçli bir çaba sarf etmiştir. Bu aşamada propaganda broşürleri, metinleri ve posterleri hem kırsal hem de kentsel ortamlarda okuryazarlık çabasının temel söylemlerini ön plana çıkarmıştır. Komünist rejim, vatandaşların okuryazarlık yanlısı fikirleri benimsemesini teşvik etmiştir. Bu aşamada Komsomol üyeleri de okuryazar olmayanlara okuryazarlık propagandasının ağızdan ağza yayılmasında ön plana çıkarılmıştır. Komsomol'un kuruluş amacı, gençlerin Komünizm ideolojinin ilkelerine uygun bir şekilde yetiştirilmesini sağlamaktadır (Özdemir, 2016, s. 28). Buna karşılık partinin propaganda faaliyetlerinde de etkili olmuştur. İlk okuma-yazmayı teşvik eden faaliyetler, köylerde alanlar oluşturmayı kapsamıştır. 1920'li yılların başlarında Bolşevikler, köylerde parti tarafından gönderilen metinlerin yerel topluluklara dağıtıldığı propaganda merkezleri olarak faaliyette bulunması için "Kırmızı Odalar" adıyla okuma odaları meydana getirmiştir.

Bolşevikler, ideolojik fikirleri yayılmasında basılı medyayı kullanma konusunda deneyimli olmalarına rağmen, ülke vatandaşlarının birçoğunun okuma yazma bilmemesi yazılı medyanın, ideolojileri yayma konusunda yetersiz kalmıştır. Yazılı medyanın yetersiz olması, posterler üzerindeki görseller yoluyla komünist rejimin ideolojik mesajlarını okuryazar olmayan insanlara basit ve akılda kalıcı şekilde anlatabilme imkânı oluşturmuştur. Posterlerden komünist rejim propaganda amaçlı yararlanmış (Zitser, 2018, s. 242; Kalkina, 2020, 132), kullanılan posterler Komünizm ideolojisinin kitlelere benimsetilmesinde önemli bir rol üstlenmiştir. Okuryazarlık kampanyası sürecinde de posterler, propaganda aracı olarak kullanılmıştır. Okuryazarlığı teşvik eden propaganda posterleri, Bolşevik Partisi’nin ideolojik söylemlerinin kitlelere duyurulmasında önemli bir görev üstlenmiştir. Posterler üzerinde yer alan görseller yoluyla okuma yazma bilmeyen insanların, verilen mesajları anlayabilmesi imkânı ortaya çıkarmıştır. Hazırlanan propaganda posterlerinde Lenin yönetimi tarafından eğitimli ve kültürlü yeni bir dünya ve yaşam tarzı ön plana çıkarılmıştır. 21 Ocak 1924 tarihinde Lenin'in ölümünden sonra da komünist rejim tarafından kitap okumanın önemini vurgulayan propaganda faaliyetleri sürdürülmüştür.

Kampanyanın altı yılı boyunca (1920'den 1926'ya), 9-49 yaş aralığındaki kişilerin okuryazarlık oranı \%12,5 artarak \%56,6'ya yükselmiştir. Toplamda 1917-1927 yılları arasında, RSFSR'deki (Rusya Sovyet Federatif Sosyalist Cumhuriyeti) 5,5 milyon kişi de dâhil olmak üzere yaklaşık 10 milyon kişiye okuma öğretilmiştir. Buna karşılık Sovyetler Birliği, Avrupa'da okuryazarlık sıralamasında yalnızca on dokuzuncu sırada yer alabilmiştir (Петрова, 2007, s. 538). 


\section{Yöntem}

20. yüzyılda ideolojik söylemlerin kitlelere benimsetilmesinde posterlerden propaganda amaçlı yararlanılmıştır. Posterler, Bolşevikler tarafından da propaganda aracı olarak etkin bir şekilde kullanılmış, bu nedenle çalışmanın posterler özelinde gerçekleştirilmesi kararlaştırılmıştır. Çalışmada 1917 Ekim Devrimi'nden sonra Lenin liderliğinde başlatılan okuryazarlık kampanyasında okumayı teşvik eden tüm propaganda posterleri çalışmanın evrenini oluşturmaktadır. Çalışma kapsamında gerçekleştirilen kapsamlı inceleme sonucunda Lenin döneminde hazırlanan konuya ilişkin 42 propaganda posterine ulaşılmaktadır. 42 propaganda posteri içerisinden evreni en iyi şekilde yansıtacağı düşünülen 9 propaganda posteri çalışmanın örneklemi olarak incelenmektedir. Çalışmanın örneklemi belirlenirken posterlerin doğrudan kitap okumayı teşvik eden söylemler içermesine, kitap okuma alışkanlığı kazandırmayı amaçlamasına, kitap okumanın yararlarına yer vermesine ve kitap okumanın ne gibi olumsuzları önleyeceğine yönelik mesajlar içermesine önem verilmiştir. Ayrıca doğrudan kitapları konu alan posterler çalışmanın örneklemi olarak seçilmiş, kitap dışındaki yayınları (örneğin gazeteler) konu alan posterler çalışmanın dışında tutulmuştur. Bu açıdan eğitime, cehalete veya okula vurgu yapan posterler yerine doğrudan kitap konulu posterler çalışmanın örneklemi olarak seçilmiştir.

Çalışma kapsamında belirlenen propaganda posterlerini incelemek için nitel araştırma yöntemleri içerisinde yer alan göstergebilimsel analiz yöntemi kullanılmaktadır. Göstergebilim, göstergelere ve göstergeler dizgesine atfedilen anlamları incelemektedir. Gösterge ise kavramların birbirlerini temsil etmek amacıyla kullanılmasını ifade etmektedir. İnsanlar, göstergeler ve göstergeler dizgesi içerisinde diğer insanlara belirli mesajlar vermeye çalışmaktadır. Geçmişi 20. yüzyıla dayanan göstergebilim alanında farklı uzmanlar tarafından çeşitli modeller ortaya konulmaktadır. Bu modellerden biri de Rus dilbilimci Roman Jakobson tarafından ortaya konulan modeldir (Çalışkan ve Doğan, 2020, s. 269).

20. yüzyılın büyük bir kısmında Jakobson, dil biliminin öndegelen bir kişisi olmuş (Kučera, 1983, s. 871), birçok ülkedeki birçok dilbilim merkeziyle yakın bağlantıları bulunmuştur (Fischer-Jørgensen, 1997, s. 13). Jakobson'a göre her konuşma olayı iki tür işlemin birbirine karıştırılmasını gerektirir. Bunlardan biri, ifadede kullanılacak dilbilimsel öğelerin seçimidir; diğeri, bu seçilmiş öğelerin tamamlanmış sözler halinde birleşimidir (Bredin, 1984, s. 89-90). Jakobson tarafından ortaya konulan modelde 6 tane (gönderen, bağlam, ileti, gönderilen, bağlantı ve kod (düzgü)) sözlü iletişim etkeni yer almaktadır. Sözlü iletişim etkenlerinin de 6 temel işlevi (duygusal, gönderimsel, çağrı, şiirsel, ilişki ve üstdil) olduğu belirtilmektedir. Çalışmada propaganda posterleri, Jakobson'un duygusal, gönderimsel, çağrı işlevleri boyutunda incelenmektedir. Duygusal işlevde mesajı veren taraf üzerine odaklanılmaktadır. Bu aşamada verilmek istenen mesaj doğrudan mesajı veren taraf üzerinden yorumlanabilmektedir. Gönderimsel işlev, mesajın hangi koşullar altında oluşturulduğunu ele almaktadır. Verilmek istenen mesajın bağlam özelinde değerlendirilmesini içeren gönderimsel işlev, mesajın oluşturulduğu zamana ve mekâna göre yorumlanmasını sağlamaktadır. Çağrı işlevinde ise mesajı alan taraf üzerine incelemede bulunulmaktadır (Rifat, 2013, s. 57). Mesajı alan taraf üzerinde oluşabilecek etki ve sonuç üzerine odaklanılmaktadır. Özetle mesajdaki çağrı boyutu ele alınmaktadır. Diğer yandan posterlerde verilmek istenen mesajların ne şekilde sunulduğunun ortaya konulabilmesi için posterlerdeki düzdeğişmece ve eğretilemeler de analiz 
edilmektedir. Düzdeğişmece, genel bir kavramı ifade etmek için kavramın yerine onu tanıtan bir temsilinin kullanılmasıdır. Eğretileme ise bir kavramı ifade etmek için kavramın kendisi yerine farklı bir kavramdan yararlanılmasıdır (Guiraud, 2016, s. 145-146).

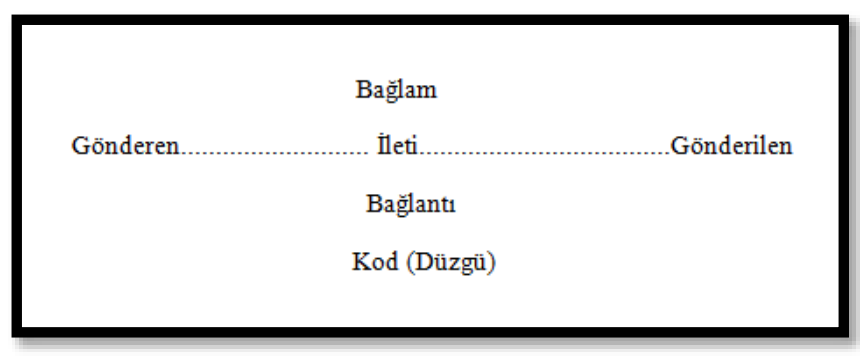

Şekil 1. Jakobson'a Göre Sözlü İletişimin Etkenleri (Fiske, 2017, s. 115).

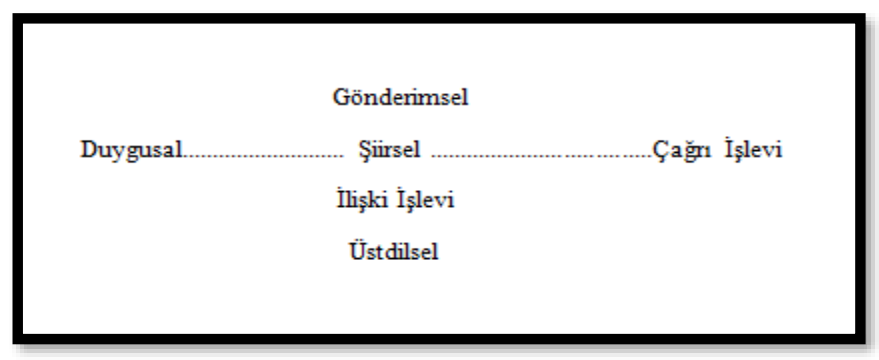

Şekil 2. Jakobson'a Göre Sözlü İletişimin Altı İşlevi (Fiske, 2017, s. 115).

Görseller, propaganda mesajlarının kitlelere aktarılmasında büyük önem taşımaktadır. Nitekim kimi zaman uzun metinler halinde kitlelere verilmek istenen propaganda mesajları, yalnızca tek bir görsel üzerinden yansıtılabilmektedir. Geçmiş dönemlerde okuma yazma bilmeyen insanlara, yazı yoluyla verilemeyen propaganda mesajları görseller üzerinden verilebilmiştir. Diğer yandan yazılı bir metindeki propaganda mesajı, yalnızca o dili bilen kişiler tarafından anlaşılabilirken, görseller üzerinden verilen propaganda mesajı evrensel bir özellik kazanabilmektedir. Görsellerde yer verilen resimlerde insanlar olduğundan daha büyük veya daha küçük sunulabilmekte, bu şekilde kitlelerin dikkatinin belli bir yöne çekilmesi sağlanabilmektedir. Diğer yandan propaganda mesaj1, yazıya oranla görseller yoluyla kitlelerin zihinlerinde daha akılda kalıcı olabilmektedir. Göstergebilimde propaganda posterlerinde kullanılan görsel ve yazılı göstergeler bir bütün olarak analiz edilerek, propaganda posterleri üzeriden verilmek istenilen propaganda mesajları ortaya konulmaya çalışılmaktadır.

\section{Bulgular ve Yorum}

Çalışmanın bu kısmında "Köleliğin Zinciri”, “Komünizm”, “Geçmiş”, “İyi İnsanlar”, “Kızıl Ordu”, “Sorumluluk”, “Konuşan İnsan”, "Mutluluk” ve "Karanlık” konulu 9 propaganda posteri göstergebilim yöntemi kullanılarak incelenmektedir.

\section{“Köleliğin Zinciri” Konulu Poster}

Köleliğin zinciri konulu poster, 1920 yılında Aleksei Aleksandrovich Radakov tarafından hazırlanmaktadır. Duygusal işlev boyutunda ele alındığında posterde bir zincirin üzerine üst üste dizilmiş kitaplar olduğu görülmektedir. Kitapların üstünde ise kuş tüyü ve bir el yer almaktadır. Posterde kitapların ağırlığından zincirin aşağı doğru eğildiği yansıtılmaktadır. Posterin arka planında fabrikalar ve siyah bir duman bulunmaktadır. 


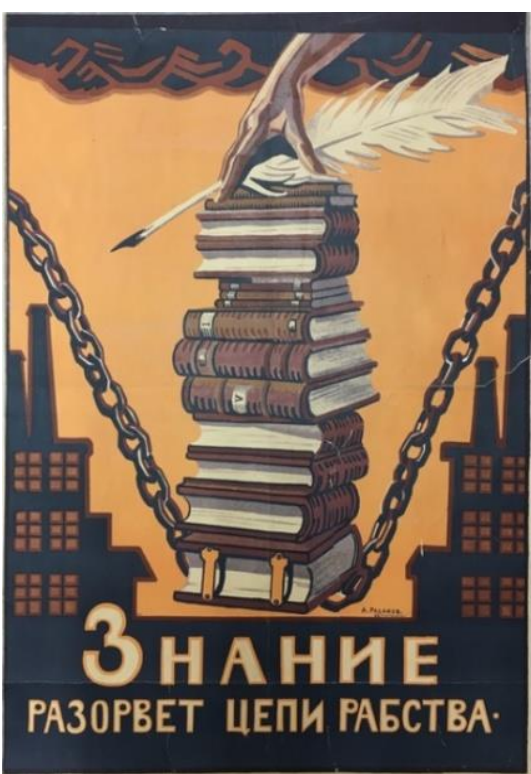

Poster 1. "Köleliğin Zinciri” Konulu Poster ${ }^{1}$ (Redavantgarde, 2020).

\section{Tablo 1}

"Köleliğin Zinciri” Konulu Poster

\begin{tabular}{|c|c|}
\hline Düzdeğişmece & $\begin{array}{l}\text { Kitaplar, kitap okuyan insanların düzdeğişmecesi } \\
\text { olarak kullanılmaktadır. }\end{array}$ \\
\hline Eğretileme & Zincir, esaretin eğretilemesi olarak kullanılmaktadır \\
\hline Duygusal İşlev & Zincirlerin üzerinde kitapların bulunması \\
\hline Gönderimsel İşlev & Kitap okumanın, kitleleri özgürleştirdiği düşüncesi \\
\hline Çağrı İşlevi & $\begin{array}{l}\text { “İnsanlar, özgür olabilmek için kitap okumalıdır” } \\
\text { şeklinde çağrıda bulunulmaktadır. }\end{array}$ \\
\hline
\end{tabular}

Gönderimsel işlev boyutunda incelendiğinde posterde yer alan kitaplar, kitap okuyan insanların düzdeğişmecesi olarak kullanılmaktadır. Posterde bulunan zincirin ise esaretin bir eğretilemesi olarak kullanıldığı ortaya çıkmaktadır. İnsanların, kitap okumadıklarında bilgisiz kalabilecekleri ve bu nedenle belirli kişi veya kişilerin esareti altına girebileceği düşüncesi posterde hâkim kılınmaya çalışılmaktadır. Bolşevik Parti, Ekim Devrimi öncesinde Rus halkının çeşitli grupların etkisi altına girdiğini ve bu gruplar tarafından emeklerinin sömürüldüğ̈nü ileri sürmektedir. Posterde yer verilen zincir, doğrudan bu grupların Rus halkı üzerindeki etkisinin bir temsili olmaktadır. Halkın, kendisini etkisi altına alan bu gruplardan kurtulmasının yolu olarak da kitaplar ön plana çıkarılmaktadır. İnsanların kitap okuyarak, iddia edilen sömürü düzeninden kurtulabileceği ileri sürülmektedir. Posterde yer alan fabrikalar ise ülkedeki üretimi temsil etmektedir. Fabrika görselleri, kitap görselleriyle bir bütün olarak ele alındığında, insanların kitap okumasıyla ülkenin sanayisinin kalkınacağına yönelik mesaj verilmeye çalışıldığı ortaya çıkabilmektedir. Bu açıdan posterde kitap okumayla birlikte

\footnotetext{
${ }^{1}$ Posterde "Bilgi, köleliğin zincirlerini kıracak (Знание разорвет цепи рабства)” уаzısı bulunmaktadır.
} 
insanların refah ve gelişmekte olan bir ülkede yaşamalarının mümkün olabileceğine yönelik algının meydana getirilmeye çalışıldığı belirtilebilmektedir. Posterde yer alan kuş tüyü ise kitapların yazımına vurgu yapmaktadır. Böylece poster üzerinden yalnızca kitapların okunmasının değil yazılmasının da önemi üzerinde durulduğu ileri sürülebilmektedir. Çağrı işlevi boyutunda ele alındığında posterde verilen mesaj üzerinden insanların esaretten kurtulması veya esaret altına girmemesi için kitap okuması gerektiği aktarılmaktadır. Kitap okumanın bilgisizliği önleyeceği ve insanları özgürleştireceği algısı üzerinden posterde insanların kitap okuma alışkanlığı elde etmesi amaçlanmaktadır. Sonuç olarak kitap okumanın insanlara bir kurtarıcı olarak sunulduğu ortaya çıkmaktadır. Bu şekilde kitap okumanın insanların hayatında ne kadar büyük bir öneme sahip olduğuna yönelik algının oluşturulması hedeflenmektedir.

\section{“Geçiş” Konulu Poster}

Geçmiş konulu poster, 1920 yılında Leonid Viktorovich Sayansky tarafindan hazırlanmaktadır. Duygusal işlev boyutunda incelendiğinde posterin sol ve sağ kısım olmak üzere iki farklı bölümden oluştuğu görülmektedir. Posterin sol tarafında elinde şişe bulunan, kıyafeti yırtık bir erkek görseline yer verilmektedir. Kişinin arkasında üzerinde $K A Б A K$ (İçki Salonu) yazan bir yapının olduğu görülmektedir. Posterin sağ tarafında ise elinde kitap bulunan bir kişi görseline yer verilmektedir. Kişinin arkasında üzerinde Читальня (Okuma Salonu) yazan bir yapı ve elinde kitap bulunan insanlar bulunmaktadır. Yapının kapısında kızıl bir bayrak ve Komünizm ideolojisinin simgesi orak ve çekiç görselleri yer almaktadır.

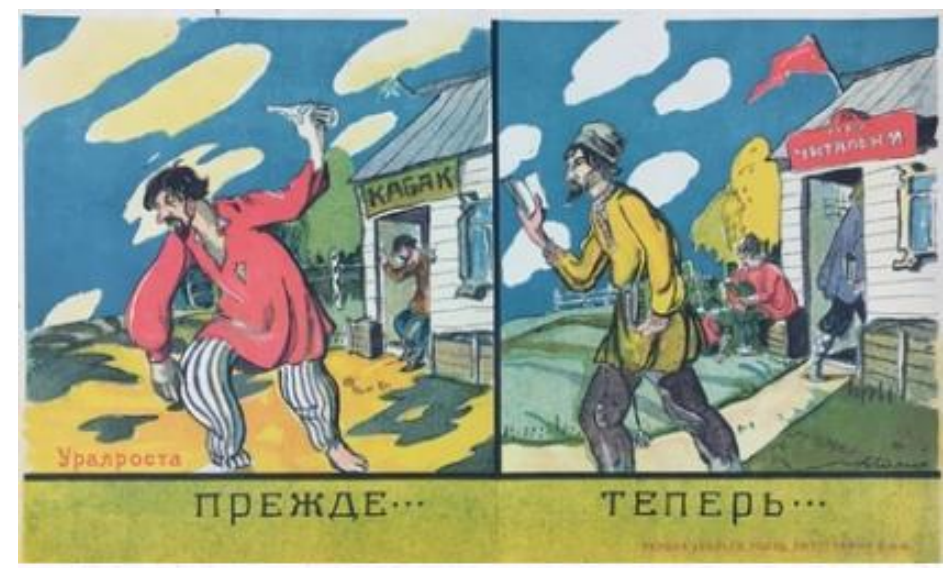

Poster 2. “Geçmiş" Konulu Poster² (Redavantgarde, 2020).

\footnotetext{
${ }^{2}$ Posterde “Önce... Şimdi... (Прежде... Теперь...)” yazısı bulunmaktadır.
} 


\section{Tablo 2}

“Geçmiş" Konulu Poster

\begin{tabular}{cc}
\hline Düzdeğişmece & $\begin{array}{r}\text { İçki şişesi, ülkedeki içki bağımlılarının; kitap, okuma alışkanlığı } \\
\text { olanların düzdeğişmecesi olarak kullanılmaktadır. }\end{array}$ \\
$\begin{array}{c}\text { Eğretileme } \\
\text { Orak ve çekiç, Komünizm ideolojisinin eğretilemesi olarak } \\
\text { kullanılmaktadır }\end{array}$ \\
$\begin{array}{c}\text { Guygusal İşlev } \\
\text { İşlev }\end{array}$ & $\begin{array}{r}\text { İçki içen erkek ve kitap okuyan erkek } \\
\text { Çağrı İşlevi }\end{array}$ \\
\hline
\end{tabular}

Gönderimsel işlev boyutunda ele alındığında posterdeki içki şişesinin, ülkedeki içki bağımlılarının, kitap ise kitap okuma alışkanlığı olanların düzdeğişmecesi olarak kullanıldığı anlaşılmaktadır. Posterdeki orak ve çekiç görselinin de Komünizm ideolojisinin eğretilemesi olarak kullanıldığı ortaya çıkmaktadır. Orak ve çekiç simgesinin dışında görselin sağında yer alan kızıl bayrak da ülkedeki komünist rejimi simgelemektedir. Böylece ülkede komünist rejimin kurulmasıyla içki içen insanlardan, kitap okuyan insanlara geçiş olduğu mesajının verilmeye çalışıldığ 1 ileri sürülebilmektedir. Posterin solunda yer alan görsel Komünizm ideolojisinin Rusya'da iktidarda olmadığı; posterin sağında yer alan görsel ise Komünizm ideolojisinin Rusya'da iktidarda olduğu dönemi yansıtmaktadır. Ülkede cehaletin ortadan kaldırılması için merkezler açılmakta (Аракелова, 1994, s. 75) ve insanların okuryazar olması teşvik edilmektedir. Rusya'da komünist rejimin iktidara gelmesiyle sosyal hayatta değişimin yaşandığına vurgu yapılmakta, insanların içki bağımlılığından uzaklaşarak, kitap okuma alışkanlığı kazandığı aktarılmaya çalışılmaktadır. Posterde insanların bir araya gelecekleri kamusal alanların içki salonları değil, okuma salonları olduğu mesajı verilmektedir. Bu şekilde insanların okuma salonlarına gelerek, doğrudan komünist rejimin propagandasına da maruz kalmalarının önü açılmaktadır. Komünist rejim, alkol karşıtı söylemlerini doğrudan propaganda posterine yansıtmakta ve alkolü bırakan (veya azaltan) insanların zamanını kitap okuyarak geçirmesini telkin etmektedir. Kitap okuyarak okuma salonlarında zaman geçirmek, içki salonlarında içki içerek zaman geçirmeye bir alternatif olarak sunulmaktadır. Diğer bir değişle komünist rejim, idealize ettiği vatandaş profilinin içki içen değil kitap okuyan bireyler olduğu mesajını vermektedir. Posterde içki içen kişinin kıyafetinin yırtık olması, alkol nedeniyle hayatının düzen içerisinde olmadığı; kitap okuyan kişinin kıyafetinin daha düzgün olmasıysa hayatının düzen içerisinde olduğu mesajını vermektedir. Çağrı işlevi boyutunda incelendiğinde posterin sağ tarafındaki görsel üzerinden komünist rejim altında ülkede idealize edilen vatandaş temsilinin sunulduğu ortaya çıkmaktadır. İdealize edilen vatandaş profili üzerinden kitlelerin okuma alışkanlığı kazanması teşvik edilmeye çalışılmaktadır.

\section{“Komünizm” Konulu Poster}

Komünizm konulu poster, 1920 yılında hazırlanmaktadır. Posteri hazırlayan/lar hakkında bilgiye ulaşılamamaktadır. Duygusal işlev boyutunda ele alındığında posterde at üzerinde bir 
insan görseline yer verildiği görülmektedir. Kanatlı bir atın üzerindeki insanın bir elinde kitap, diğer elinde ise yanan bir meşale tutuğu ve eski çağlardan kalma bir kıyafet giydiği resmedilmektedir. Posterin arka planında şehir ve siyah duman görseli bulunmaktadır. Posterdeki yazının solunda da Komünizm ideolojisinin simgesi orak ve çekiç görseli yer almaktadır.

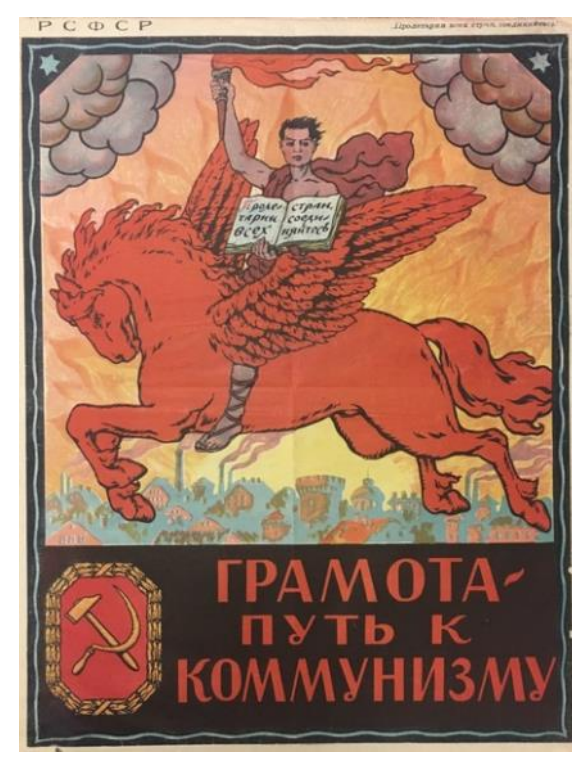

Poster 3. "Komünizm” Konulu Poster ${ }^{3}$ (Redavantgarde, 2020).

Tablo 3

“Komünizm” Konulu Poster

Düzdeğişmece $\quad$ Kitap, okuma alışkanlığı olan insanların düzdeğişmecesi olarak
kullanılmaktadır.

Eğretileme Meşale, aydınlık geleceğin bir eğretilemesi olarak kullanılmaktadır.

Duygusal İşlev $\quad$ At üzerinde elinde meşale ve kitap olan kişi

\begin{tabular}{cc} 
Gönderimsel İşlev & $\begin{array}{r}\text { Kitap okumanın, Komünizm ideolojisinin bir parçası olduğu } \\
\text { düşüncesi }\end{array}$ \\
\hline Çağrı İşlevi & $\begin{array}{r}\text { "İnsanlar, Komünizm ideolojisini benimsediklerinde kitap } \\
\text { okumalıdır" şeklinde çağrıda bulunulmaktadır. }\end{array}$ \\
\hline
\end{tabular}

Gönderimsel işlev boyutunda incelendiğinde posterdeki kitap görselinin, Rusya'daki okuryazar insanların ve kitap okuma alışkanlığı olan insanların bir düzdeğişmecesi olarak kullanıldığı ortaya çıkmaktadır. Posterdeki meşale ise aydınlık geleceğin bir eğretilemesi olarak kullanılmaktadır. Kanatlı bir at üzerinde yer alan ve eski çağlardan kalma bir kıyafet giyen erkek görseli ile postere mitolojik bir algı kazandırılmaya çalışılmaktadır. Posterdeki kişinin bir elinde kitap bir elinde de meşale taşımasıyla siyah bulutları uzaklaştırdığı algısı oluşabilmektedir. Böylece okuryazarlığın ve kitap okumanın, insanları aydınlık bir geleceğe götüreceği mesajı verilebilmektedir. Posterde yer alan orak ve çekiç Komünizm ideolojisinin

\footnotetext{
${ }^{3}$ Posterde “Okuryazarlık, Komünizm’e giden yoldur (Грамота - путь к коммунизму)” уazısı bulunmaktadır.
} 
eğretilemesi olarak ön plana çıkarılmakta, insanların okuryazar olmasının ve kitap okuma alışkanlığı elde etmesinin ülkedeki komünist yönetim tarafından desteklendiği algısı oluşturulmaya çalışılmaktadır. Çağrı işlevi boyutunda ele alındığında posterde insanların aydınlık bir gelecek için okuryazar olması ve kitap okuma alışkanlığı kazanması gerektiğine yönelik mesaj verildiği ortaya çıkmaktadır. Poster, Komünizm ideolojisini kitlelere tanıtma rolü üstlenmektedir. Okuma yazma bilinmemesine karşı mücadelenin nihai amacının, işçileri ve köylüleri Sosyalizm'in inşası görevine dahil etmek olduğu ilan edilmektedir (горюнова, 2012, s. 24). Bu açıdan kitap okumanın, Komünizm ideolojisinin bir parçası olduğu algısı üzerinden insanların okuma alışkanlığı kazanması amaçlanmaktadır.

\section{“İyi Insanlar" Konulu Poster}

İyi insanlar konulu poster, 1920 yılında Ivan Vasilyevich Simakov tarafindan hazırlanmaktadır. Duygusal işlev boyutunda incelendiğinde posterin merkezinde bir insanın kitap okuduğu resmedilmektedir. Posterin altında da bir yazının olduğu görülmektedir. Kitap okuyan insanın çevresinde Lenin, Karl Marx gibi insan görselleri ve kitaplar yer almaktadır.

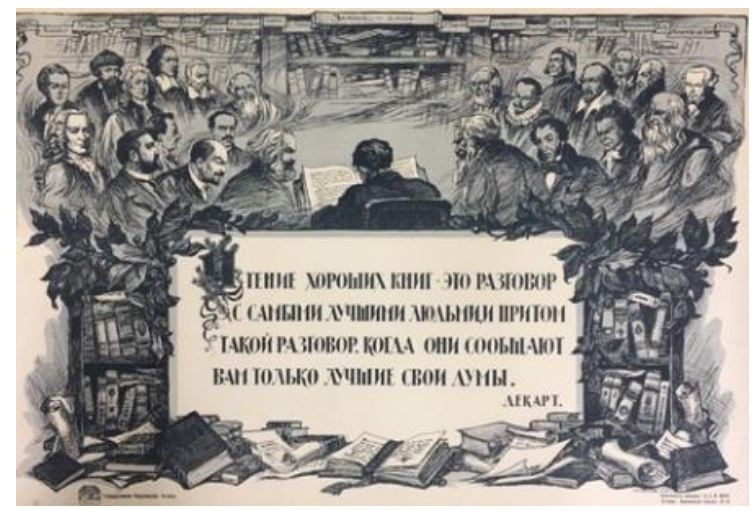

Poster 4. İyi İnsanlar Konulu Poster ${ }^{4}$ (Redavantgarde, 2020).

\section{Tablo 4}

"İyi Insanlar" Konulu Poster

Kitap, Rusya'daki okuryazar ve kitap okuma alışkanlığı olan
insanların düzdeğişmecesi olarak kullanılmaktadır.

Eğgretileme $\quad$ Lenin/Marx, Komünizm ideolojisinin eğretilemesi olarak
kullanılmaktadır.

Duygusal İşlev $\quad$ Çevresinde insanlar olan, kitap okuyan bir kişi
Gönderimsel İşlev Kitap okumanın, insanları iyi insanlarla buluşturacağı düşüncesi
Çağrı İşlevi “İnsanlar, komünist rejim tarafından belirtilen kitapları okumalıdır” şeklinde çağrıda bulunulmaktadır.

\footnotetext{
${ }^{4}$ Posterde "İyi kitaplar okumak, en iyi insanlarla konuşmaktır ve dahası, böyle bir konuşmada size sadece en iyi düşüncelerini söylerler. Descartes (Чтение хороших книг - это разговор с самыми лучшими людьми, и притом такой разговор, когда они сообщают вам только лучшие свои думы. Декарт)" yazısı bulunmaktadır.
} 
Gönderimsel işlev boyutunda ele alındığında posterde yer alan kitapların, Rusya'daki okuryazar ve kitap okuma alışkanlığı olan insanların düzdeğişmecesi olarak kullanıldığı ortaya çıkmaktadır. Posterdeki Lenin ve Marx'ın görselleri de Komünizm ideolojisinin eğretilemesi olarak kullanılmaktadır. Posterdeki görsel ve yazılı kodlar birlikte incelendiğinde insanlara hangi kitapları okumaları gerektiğiyle ilgili bir yönlendirmenin yapıldığı ortaya çıkmaktadır. İdeolojik retorik, günlük yaşama girmekte ve günlük dilin bir parçası olmaktadır (Глущенко, 2015, s. 278). Posterde Komünizm ideolojisi temelinde "İyi kitaplar ve iyi insanlar" söylemi üzerinden Lenin ve Marx'ın görsellerine yer verilmesiyle insanların Lenin ve Marx'ın düşüncelerini yansıtan kitapları okumasının teşvik edildiği belirtilebilmektedir. $\mathrm{Bu}$ açıdan insanların okuyacağı kitaplar üzerinde ideolojik bir yönlendirmenin yapıldığı ortaya çıkmaktadır. Posterde kitap okuyan kişinin yanında bulunan insanlar üzerinden kitap okunduğunda insanların farklı insanların düşüncelerine ulaşabileceği mesajı verilebilmektedir. İnsanların, okudukları kitapların yazarlarını hayatta olsa da olmasa da tıpkı yanlarındaymış gibi kitaplar üzerinden tanıyabilecekleri algısı oluşabilmektedir. Çağrı işlevi boyutunda incelendiğinde de posterde insanların komünist rejimin ideolojisini yansıtan kitapları okumasının teşvik edildiği sonucuna ulaşılabilmektedir. Bu aşamada posterde Komünizm ideolojisine muhalif kitapların eleştirilmesinin veya onların okunmamasının telkin edilmesi yerine Lenin ve Marx'n görselleri üzerinden kitlelerin Komünizm ideolojisini aktaran kitapları okumasi istenmektedir.

\section{“Kızıl Ordu” Konulu Poster}

Kızıl Ordu konulu Poster, 1920 yılında hazırlanmaktadır. Posteri hazırlayan/lar hakkında bilgiye ulaşılamamaktadır. Duygusal işlev boyutunda ele alındığında posterin sol ve sağ olmak üzere iki bölümden oluştuğu görülmektedir. Posterin solunda elleri ve ayakları zincirli, gözleri ise bağlı büyük bir erkek görseline yer verilmektedir. Erkek görselinin çevresinde ise bir smokin, bir din görevlisi kıyafeti, bir asker üniforması, iki de yerel kıyafetler içerisinde olmak üzere beş kişinin olduğu görülmektedir. Yerel kıyafetler içerisindeki kişilerden birinin büyük erkeğe içki içirdiği, diğerinin de cebine kesici bir alet koyduğu yansitılmaktadır. Smokin içerisindeki kişinin büyük erkeğe para verdiği, asker üniforması içerisindeki kişinin büyük erkeğin ayaklarını zincirlediği, din görevlisi kıyafeti içerisindeki kişinin de büyük erkeğin başında durduğu görülmektedir. Posterin arka planında bulut görseli bulunmaktadır. Posterin sağında, üzerinde АЗБУКА КОММУНИЗМА (Komünizm'in AВС'si) yazan ve yıldız ve orak ve çekiç görseli olan bir kitap taşıyan, mutlu büyük erkek görseline yer verilmektedir. Posterin bu kısmında posterin solunda yer alan diğer kişilerin kaçmakta olduğu görülmektedir. Posterin arka planında da güneş görseline yer verilmektedir. 


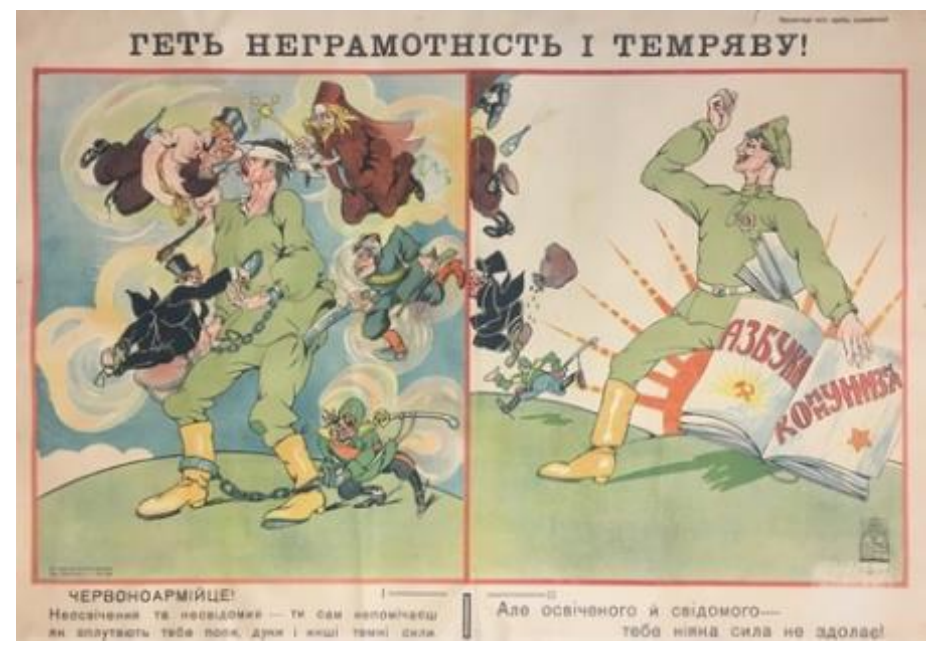

Poster 5. Kiz1l Ordu Konulu Poster ${ }^{5}$ (Redavantgarde, 2020).

\section{Tablo 5}

“Kızll Ordu” Konulu Poster

Düzdeğişmece

Eğretileme

Duygusal İşlev
Posterde yer alan insanlar, ülkedeki çeşitli gurupların düzdeğişmecesi olarak kullanılmaktadır.

Zincir, esaretin eğretilemesi olarak kullanılmaktadır.

$$
\begin{array}{cc}
\text { Gönderimsel İşlev } & \begin{array}{c}
\text { Komünizm ideolojisi temelli kitap okuyan insanın özgürleşeceği } \\
\text { düşüncesi }
\end{array} \\
\text { Çağrı İşlevi } & \begin{array}{c}
\text { "İnsanlar, özgür bir şekilde yaşamaları için Komünizm ideolojisi } \\
\text { temelli kitaplar okumalıdır” şeklinde çağrıda bulunulmaktadır. }
\end{array}
\end{array}
$$

Gönderimsel işlev boyutunda incelendiğinde posterde yer alan insanların ülkedeki çeşitli gurupların düzdeğişmecesi olarak kullanıldığı ortaya çıkmaktadır. Posterde yer alan zincir görselleri ise esaretin eğretilemesi olarak kullanılmaktadır. Posterdeki büyük erkek görselinin gerek posterdeki yazılı koddan gerekse giydiği üniformadan Kızıl Ordu'yu temsil ettiği anlaşılmaktadır. Posterdeki büyük erkek görselinin gözlerinin bağlanması ise çevresinde yaşananlardan habersiz bırakıldığı algısını oluşturmaktadır. Posterin solunda yer alan görsel üzerinden Komünizm ideolojisinin ülkede egemen olmadığında insanların çeşitli grupların etkisinde kalabileceğine yönelik mesaj verilmektedir. Posterin sağında büyük erkeğin gözlerinin bağının açılması ve zincirlerinden kurtulması ile özgürleştiği algısı oluşturulmaya çalışılmaktadır. Posterin solunda yer alan insanların, büyük erkeği terk etmesiyle de büyük erkek üzerindeki etkilerinin son bulduğu mesajı verilmektedir. Bu aşamada büyük erkeğin

\footnotetext{
${ }^{5}$ Posterin başında "Cehalet ve karanlıktan kurtulun (Геть неграмотність і темряву!)" yazısı bulunmaktadır. Posterin altında ise "Kızıl Ordu! Eğitimsiz ve bilinçsiz - rahipler, dükler ve diğer karanlık güçler tarafindan nasıl dolandığınızı fark etmiyorsunuz. Ama aydınlanmış ve bilinçli - hiçbir güç sizi alt edemez! (Червоноармійце! Неосвічений та несвідомий - ти сам непомічаэш як оплутають тебе попи, дуки і инші темні сили. Але освіченого й свідомого - тебе ніякя сила не здолаэ!)" yazıları yer almaktadır.
} 
elinde yer alan kitap sayesinde özgürleştiği algısı oluşturulmaktadır. Kitapta yazan Komünizm 'in $A B C$ 'si yazısı ve kitabın üzerinde yıldız ve orak ve çekiç görsellerinin bulunması ile de doğrudan Komünizm ideolojisinin insanların özgüleşmesini sağladığı mesajı verilmektedir. Böylece kitapların aracı olduğu ve insanları özgürleştirenin aslında Komünizm ideolojisi olduğu algısı oluşturulmaya çalışılmaktadır. Cehaletin kaldırılması önce Kızıl Ordu'yu, daha sonra nüfusun geri kalanını kapsamaktadır (горюнова, 2012, s. 24). İç savaştaki rolü ve rejimin varlığını sürdürebilmesi açısından önemi gibi nedenler, kitaplar üzerinden Kızıl Ordu'ya yönelik Komünizm ideolojisinin propagandasının yapılmasının önemini arttırmaktadır. Posterin solunda bulut, sağında ise güneş görselinin olmasıyla Komünizm'le bulutların dağıldığı ve güneş açtığı algısı oluşmaktadır. Bu açıdan posterde yer alan güneş görseli üzerinden Komünizm'i konu alan kitabın okunmasıyla insanların aydınlık bir geleceğe sahip olabileceğine yönelik mesajın verildiği ileri sürülebilmektedir. Çağrı işlevi boyutunda ele alındığında posterde insanların çeşitli grupların etkisinden uzaklaşması ve özgürce yaşayabilmesi için Komünizm'i öğrenmesi gerektiği mesajı verilmektedir. Bu aşamada da okuryazar olması ve kitap okuma alışkanlığı elde etmesi gerektiğine yönelik çağrıda bulunulmaktadir.

\section{"Sorumluluk" Konulu Poster}

Sorumluluk konulu poster, 1920 yilında Viktor Semenovich Ivanov tarafindan hazırlanmaktadır. Duygusal işlev boyutunda incelendiğinde posterde kitap okumakta olan bir erkek ve bir kadın görseline yer verilmektedir. Posterin merkezinde ise kitapların bulunduğu görülmektedir. Posterde siyah fona yer verilmektedir.

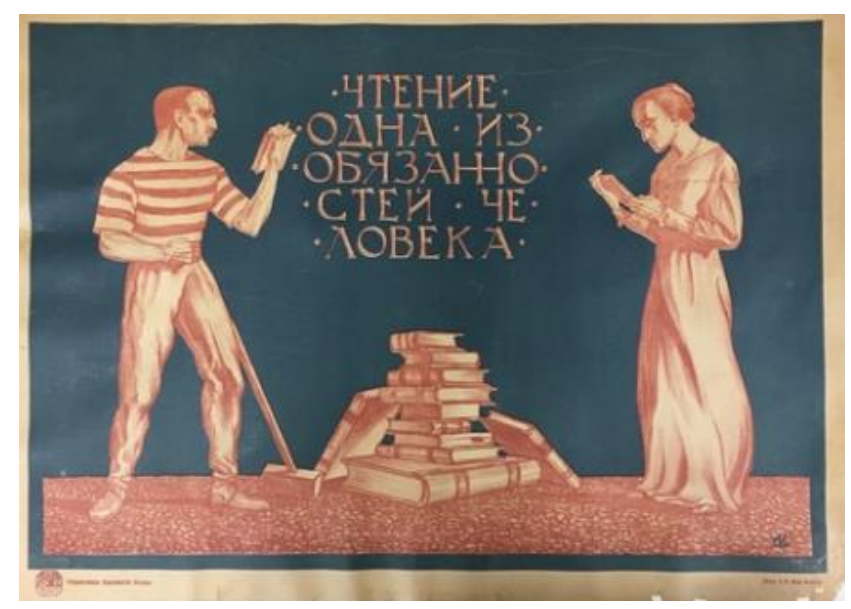

Poster 6. Sorumluluk Konulu Poster ${ }^{6}$ (Redavantgarde, 2020).

\footnotetext{
${ }^{6}$ Posterde "Okumak, bir kişinin sorumluluklarından biridir (Чтение - одна из обязанностей человека) уazısı bulunmaktadır.
} 


\section{Tablo 6}

"Sorumluluk" Konulu Poster

\begin{tabular}{|c|c|}
\hline Düzdeğişmece & $\begin{array}{c}\text { İnsanlar, Rusya’daki insanların düzdeğişmecesi olarak } \\
\text { kullanılmaktadır. }\end{array}$ \\
\hline Eğretileme & $\begin{array}{c}\text { Kitaplar, okuryazarlığın ve kitap okuma alışkanlığının } \\
\text { eğretilemesi olarak kullanılmaktadır. }\end{array}$ \\
\hline Duygusal İşlev & Kitaplar ve kitap okuyan erkek ve kadın \\
\hline $\begin{array}{l}\text { Gönderimsel } \\
\text { İşlev }\end{array}$ & $\begin{array}{c}\text { Kitap okumanın insanların rutin yaptıkları eylemlerden biri } \\
\text { olması düşüncesi }\end{array}$ \\
\hline Çağrı İşlevi & $\begin{array}{l}\text { "İnsanlar, sorumluluk bilincinde kitap okumalıdır” şeklinde } \\
\text { çağrıda bulunulmaktadır. }\end{array}$ \\
\hline
\end{tabular}

Gönderimsel işlev boyutunda ele alındığında posterde yer alan insanların Rusya'daki insanların düzdeğişmecesi olarak kullanıldığı ortaya çıkmaktadır. Posterdeki kitap görselleri ise okuryazarlığın ve kitap okuma alışkanlığının eğretilemesi olarak kullanılmaktadır. Posterde siyah fonun kullanılması, insanların doğrudan kitaplara ve kitap okuyan kişilere odaklanmasına sağlamaktadır. Posterdeki görsel ve yazılı kodlardan kitap okumanın, günlük hayatın rutin işlerinden biri gibi algılanmasına çalışıldığı ortaya çıkmaktadır. Diğer yandan insanların kitap okuyarak, bilgilenmesinin de bir sorumluluk olarak algılanmasına çalışılmaktadır. Posterde yalın bir anlatım kullanılmakta ve insanlar, doğrudan kitap okuyan insan görsellerine odaklanabilmektedir. Bu şekilde okuma yazma bilmeyen bir kişinin posterdeki yazılı mesajı anlamasa da görseller üzerinden kitap okuyan kişilerin ön plana çıkarılarak, kitap okumanın teşvik edildiği algısına kapılması mümkün olabilmektedir. Kadınlara okumayı ve yazmayı öğretmek "yeni Sovyet kadını" yapısının uygulanmasında temel bir aşamayı oluşturmaktadır (Bacexa, 2018, s. 150). Bu açıdan ele alındığında posterde erkek görseli ile kadın görselinin bir arada kullanılmasıyla kadınların da erkekler gibi eşit koşullarda eğitim almasına ve kitap okuma alışkanlığı kazanmasına yönelik algının meydana getirilmeye çalışıldığı söylenebilmektedir. Çağrı işlevi boyutunda incelendiğinde de posterde kitap okumanın insanlar tarafindan bir sorumluluk olarak algılanmasına çalışılarak, kitlelerin kitap okuma alışkanlığı kazanmasının teşvik edildiği ortaya çıkmaktadır.

\section{“Konuşan İnsan” Konulu Poster}

Konuşan insan konulu poster, 1920 yılında Viktor Semenovich Ivanov tarafindan hazırlanmaktadır. Duygusal işlev boyutunda ele alındığında posterde devasa büyüklükteki iki elin devasa büyüklükte bir kitabı tuttuğu görülmektedir. Kitabın altında bir sahne bulunmakta ve sahnenin üzerinde de bir kişi yer almaktadır. Kitabın çevresinde insanların toplandığı ve pankartlar taşıdıkları aktarılmaktadır. Posterin arka planında yapıların ve dumanların olduğu görülmektedir. 


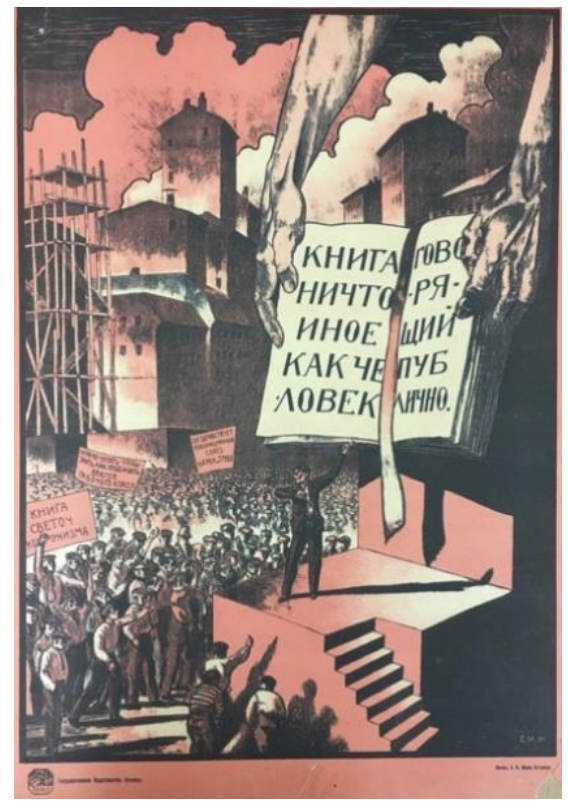

Poster 7. "Konuşan İnsan” Konulu Poster ${ }^{7}$ (Redavantgarde, 2020).

\section{Tablo 7}

“Konuşan İnsan” Konulu Poster

\begin{tabular}{|c|c|}
\hline Düzdeğişmece & $\begin{array}{c}\text { İnsanlar, Rusya'daki insanların düzdeğişmecesi olarak } \\
\text { kullanılmaktadır. }\end{array}$ \\
\hline Ĕgretileme & $\begin{array}{c}\text { Kitap, okuryazarlığın ve kitap okuma alışkanlığının bir } \\
\text { eğretilemesi olarak kullanılmaktadır. }\end{array}$ \\
\hline Duygusal İşlev & Devasa bir kitap ve çevresindeki insanlar \\
\hline Gönderimsel İşlev & Devrimin temelinde kitap okumanın olduğu düşüncesi \\
\hline Çağrı İşlevi & $\begin{array}{c}\text { "Devrim için kitap okunmalıdır” şeklinde çağrıda } \\
\text { bulunulmaktadır. }\end{array}$ \\
\hline
\end{tabular}

Gönderimsel işlev boyutunda incelendiğinde posterde yer alan insanların Rusya'daki insanların düzdeğişmecesi olarak kullanıldığı ortaya çıkmaktadır. Posterde yer alan devasa büyüklükteki kitap görseli de okuryazarlığın ve kitap okuma alışkanlığının bir eğretilemesi olarak kullanılmaktadır. Posterdeki görsel ve yazılı kodlardan kitap okumanın insanları bilinçlendirdiği ve devrime giden yolu açtığı mesajı verilmektedir. Bu şekilde 1917 yılında ülkede gerçekleşen Ekim Devrimi'nin ve beraberinde kurulan komünist rejimin temelinde de kitap okumanın yattığına yönelik algı oluşturulmaktadır. Posterdeki devasa büyüklükteki ellerin kitabı uzatması, insanlara kitap okuma imkânının verildiği düşüncesini meydana getirebilmektedir. Posterde yer alan pankartlarda yazan yazılarda insanların haklarını

\footnotetext{
${ }^{7}$ Posterde yer alan kitabın içerisinde "Kitap, toplum içinde konuşan bir insandan başka bir şey değil (Книга ничто иное как человек говорящий публично)" yazısı bulunmaktadır. Posterdeki insanların taşıdı ğı pankartlarda ise "Kitap, Komünizm'in feneridir! (Книга - светоч коммунизма!)", "İşçi sınıfının düşmanlarını nasıl yeneceğinizi öğrenmek için okumalısınız! (Нужно читать чтобы знать, как побеждать врагов рабочего класса!)" ve "Yaşasın devrimci BİLIMM ve İŞ BİRLİĞİ! (Да здравствует революционный СОЮЗ НАУКИ и ТРУДА!)" yazıları yer almaktadır.
} 
savunmalarında kitap okumanın önemli rolü olduğu üzerinde durulmaktadır. Posterdeki sahnede konuşan kişinin, arkasında bulunan devasa kitaptan esinlenerek konuştuğuna yönelik alg1 oluşturulmaktadır. Kitap okumanın insanların Komünizm ideolojisinin öğretilerini öğrenmesinde bir araç olduğu mesajı verilmektedir. Kitap, mücadele kavramıyla simgeleştirilmekte ve insanların emeklerinin sömürülmesine karşı harekete geçmesinde kitap okumanın önemli olduğu savunulmaktadır. Devrim ve iç savaş koşullarında hızlandırılmış siyasal eğitim Bolşevik devlet mekanizmasının ayrılmaz bir parçası haline gelmektedir. Bolşevik tarzda siyasi sertleşme, doğal devrimci eğitim dönemini oluşturmaktadır (Липатова, 2012, s. 85). Çağrı işlevi boyutunda ele alındığında da posterde devrimci eğitim söylemlerinin kitap okumanın teşvik edilmesine yönelik propagandada ön plana çıktığı anlaşılmaktadır. İnsanların kitap okuyarak devrimci bir ruh kazandığı ve düşmanlarına karşı mücadeleye hazır olduğu algıları oluşturulmakta, bu şekilde de kitap okumanın teşvik edildiği ileri sürülebilmektedir.

\section{“Mutluluk" Konulu Poster}

Mutluluk konulu poster, 1921 yılında Kogout Nikolay Nikolaevich tarafindan hazırlanmaktadır. Duygusal işlev boyutunda incelendiğinde posterde devasa boyutta bir kitap görselinin bulunduğu görülmektedir. Kitabın önünde başında Kızıl Ordu askerinin şapkası bulunan bir kişinin kürsüde olduğu ve çevresinde de kızıl pankartlar taşıyan insanların yer aldığı yansitılmaktadır. Posterin arka planında da ev görsellerine yer verilmektedir. Posterdeki binaların üzerinde sırasıyla ТРУД (İŞ), ИСКУССТВО (SANAT) ve НАУКА (BİLIM) yazıları bulunmaktadır.

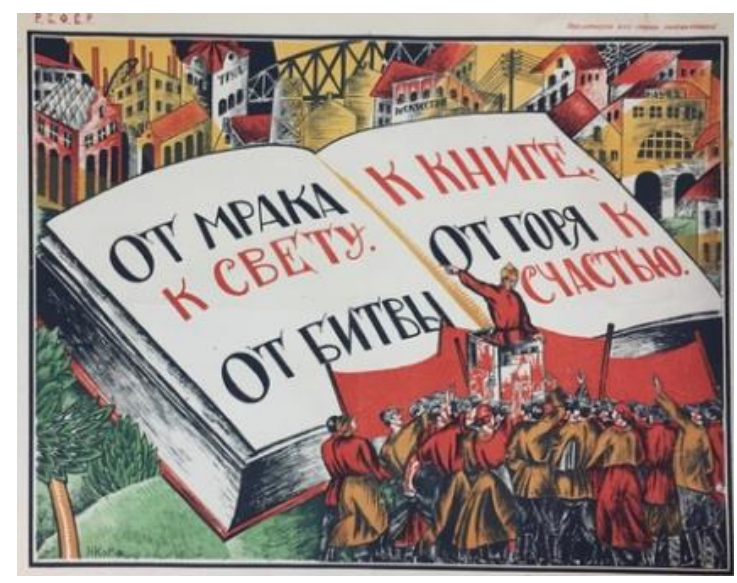

Poster 8. "Mutluluk" Konulu Poster ${ }^{8}$ (Redavantgarde, 2020).

\footnotetext{
${ }^{8}$ Posterdeki kitabın içerisinde "Karanlıktan ışığa. Savaştan kitaba. Kederden mutluluğa (От мрака к свету. От битвы к книге. От горя к счастью)" yazısı bulunmaktadır.
} 
Tablo 8

"Mutluluk" Konulu Poster

\begin{tabular}{|c|c|}
\hline Düzdeğişmece & $\begin{array}{l}\text { İnsanlar, Rusya'daki insanların düzdeğişmecesi olarak } \\
\text { kullanılmaktadır. }\end{array}$ \\
\hline Eğretileme & $\begin{array}{c}\text { Kitap, okuryazarlığın ve kitap okuma alışkanlığının bir } \\
\text { eğretilemesi olarak kullanılmaktadır. }\end{array}$ \\
\hline Duygusal İşlev & Devasa bir kitap ve çevresindeki insanlar \\
\hline Gönderimsel İşlev & Kitap okumanın huzur ve mutluluk getirdiği düşüncesi \\
\hline Çağrı İşlevi & $\begin{array}{c}\text { "Huzur ve mutlu bir yaşam için kitap okunmalıdır" şeklinde } \\
\text { çağrıda bulunulmaktadır. }\end{array}$ \\
\hline
\end{tabular}

Gönderimsel işlev boyutunda incelendiğinde posterde yer alan insanların Rusya'daki insanların düzdeğişmecesi olarak kullanıldığı ortaya çıkmaktadır. Posterde yer alan devasa büyüklükteki kitap görseli de okuryazarlığın ve kitap okuma alışkanlığının bir eğretilemesi olarak kullanılmaktadır. Posterdeki binaların üzerinde yazan Rusça kelimelerden, burasının Rusya'da bir yer olduğu algısı oluşabilmektedir. Posterde kürsüde olan ve başında Kızıl Ordu askeri şapkası bulunan kişi, Kızıl Ordu'yu temsil etmektedir. Ayrıca posterde insanların kızıl bayraklar taşımasıyla da komünist rejime atıfta bulunulduğu ileri sürülebilmektedir. Bu şekilde komünist rejimle birlikte insanların kitap okumasının teşvik edildiğine yönelik algının oluşturulmaya çalışıldığ 1 belirtilebilmektedir. Posterde kürsüde bulunan insanın ve çevresindeki diğer insanların arkasında devasa büyüklükte kitabın olmasıyla insanların bir araya gelmesinde kitabın etkili olduğu mesajı verilebilmektedir. Posterdeki yazılı kodlardan insanların huzurlu ve mutlu bir yaşam sürmesi için kitap okuması gerektiğine yönelik alg1 oluşturulmaktadır. Diğer yandan posterde "Karanlıktan 1şı̆̆a, kederden mutluluğa" şeklinde karşıt kavramlara yer verilmektedir. Buna karşılık "Savaştan kitaba” söyleminde savaşın karşıtı olan barış kelimesi yerine kitap kelimesi kullanılmaktadır. Bu şekilde kitap kavramının toplumda barış şeklinde algılanmasına çalışıldığı söylenebilmektedir. Çağrı işlevi boyutunda incelendiğinde de posterde insanların karanlıktan uzaklaşıp, aydınlık bir geleceğe ulaşabilmesi için kitap okumasının teşvik edildiği ortaya çıkmaktadır.

\section{“Karanlı" Konulu Poster}

Karanlık konulu poster, 1921 yılında Ivan Vasilyevich Simakov tarafindan hazırlanmaktadır. Duygusal işlev boyutunda ele alındığında posterde arkalarını dönmüş vaziyetteki insanların kitap okuduğu resmedilmektedir. Kitap okuyan insanların çevresinde siyah bulutların olduğu görülmektedir. Posterin arka planında ise güneş görseline yer verilmektedir. Posterin en üstünde Rusya Sovyet Federatif Sosyalist Cumhuriyeti'nin kısaltması РСФСР (Российская Советская Федеративная Социалистическая Республика) vе пролетарии всех стран соединяйтесь (Bütün ülkelerin işçileri, birleşin!) yazısı bulunmaktadır. 


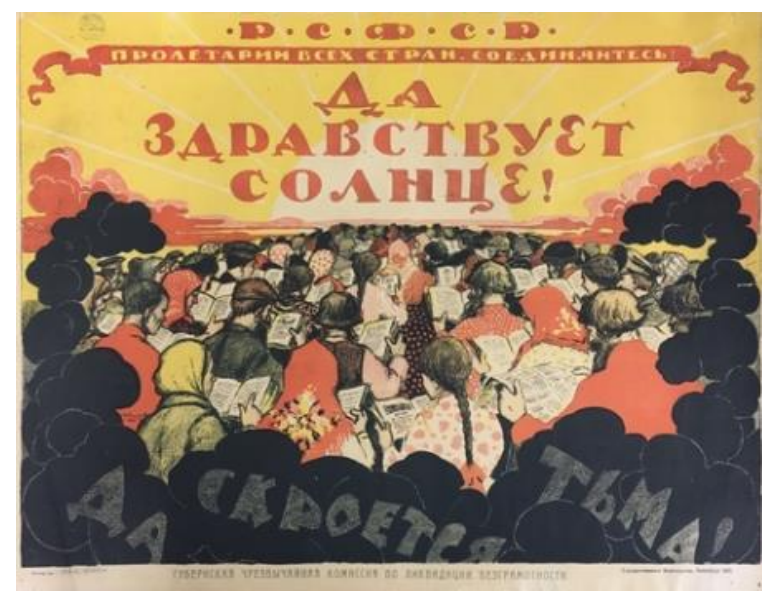

Poster 9. Karanlık Konulu Poster ${ }^{9}$ (Redavantgarde, 2020).

\section{Tablo 9}

"Karanllk" Konulu Poster

\begin{tabular}{|c|c|}
\hline Düzdeğişmece & $\begin{array}{c}\text { İnsanlar, Rusya'daki insanların düzdeğişmecesi olarak } \\
\text { kullanılmaktadır. }\end{array}$ \\
\hline Ĕgretileme & $\begin{array}{l}\text { Siyah bulut, kötü günlerin eğretilemesi olarak } \\
\text { kullanılmaktadır. }\end{array}$ \\
\hline Duygusal İşlev & Siyah bulutlar ve kitap okuyan insanlar \\
\hline $\begin{array}{l}\text { Gönderimsel } \\
\text { İşlev }\end{array}$ & Kitap okumanın insanları aydınlığa kavuşturacağı düşüncesi \\
\hline Çağrı İşlevi & $\begin{array}{c}\text { "İnsanlar, aydınlık bir yaşam için kitap okumalıdır” şeklinde } \\
\text { çağrıda bulunulmaktadır. }\end{array}$ \\
\hline
\end{tabular}

Gönderimsel işlev boyutunda incelendiğinde posterde yer alan insanların Rusya'daki insanların düzdeğişmecesi olarak kullanıldığı ortaya çıkmaktadır. Posterde yer alan siyah bulutlar ise kötü günlerin eğretilemesi olarak kullanılmaktadır. Posterin üstündeki $Р С Ф С P$ yazısından posterde yer alan insanların Rusya Sovyet Federatif Sosyalist Cumhuriyeti'ndeki insanlar olduğu algısı oluşabilmektedir. "Bütün ülkelerin işçileri, birleşin!” söylemi, Komünist Manifesto kaynaklı siyasi bir slogandır. Posterde bu slogana yer verilmesiyle doğrudan Komünizm'e vurgu yapıldığı ileri sürülebilmektedir. Posterde kitap okuyan insanların güneşin aydınlattığı yöne doğru durmaları ve siyah dumanlara arkalarını dönmeleriyle kitap okuyarak karanlıklardan aydınlığa kavuşulacağına yönelik mesaj verilmektedir. Posterde siyah bulut olarak da neyin ifade edildiği herhangi bir göstergeyle belirtilmemektedir. Karanlık olarak, Çarlık rejiminin mi, milliyetçi bir yönetimin mi veya herhangi bir başka şeyin mi ifade edildiği aktarılmamaktadır. Posterde, çalışma kapsamında incelenen diğer posterlerde olduğu gibi Komünizm ideolojisine muhalif kitapların okunmaması yönünde herhangi bir telkinde bulunulmadığ 1 ortaya çıkmaktadır. Diğer yandan posterde insanların Komünizm ideolojisini öğreten ve benimseten kitapları okuması gerektiğine yönelik herhangi bir göstergenin kullanılmadığı da anlaşılmaktadır. Bu açıdan posterin temel mesajı amacının ideolojik

\footnotetext{
9 Posterde "Güneş çok yaşa! Karanlık saklansın! (Да здравствует солнце! Да скроется тьма!)” уazısı
} bulunmaktadir. 
söylemlerden uzak, doğrudan kitap okuma alışkanlığının kazandırılması olduğu söylenebilmektedir. Çağrı işlevi boyutunda ele alındığında da posterde kötü günlerden uzaklaşabilmesi ve huzurlu ve mutlu bir geleceğe ulaşabilmesi için insanların kitap okuması gerektiğine yönelik algının oluşturulmaya çalışıldığı söylenebilmektedir. Posterde kitap bir kurtarıcı olarak ön plana çıkarılmakta, bu şekilde kitleler nezdinde kitap okumanın teşvik edilmesine çalışılmaktadır.

\section{Sonuç}

Çalışmada incelenen posterlerde, Rusya'da okuryazarlığın arttırılmasına ve okuma alışkanlığının kazandırılmasına yönelik farklı mesajlar üzerinden çeşitli propaganda posterlerinin hazırlandığı ortaya çıkmaktadır. Bu aşamada Komünizm ideolojisinin doğrudan propaganda posterlerine etkisi yansımaktadır. Propaganda posterleri üzerinden okuryazarlığın ve kitap okumanın doğrudan Komünizm ideolojisi ile bağlantılı olduğu algısı oluşturulmaya çalışılmakta, insanların kitap okuyarak Komünizm ideolojisinin öğretilerini öğrenebileceğine ve Komünizm ideolojisinin idealize ettiği yaşam tarzına kavuşabileceğine yönelik mesaj verilmektedir.

Posterlerde kullanılan eğretilemeler üzerinden kitap okuyan insanların komünist rejim altında yaşayan insanlar olduğu aktarılmaktadır. Bu şekilde komünist yönetim vurgusu ve komünist yönetimin insanların yaşamları üzerindeki etkisi doğrudan posterlere yansitılmaktadır. İnsanların kitap okunmasında Komünizm ideolojisinin etkili olduğuna yönelik algı oluşturulmaya çalışılmaktadır. Diğer yandan ülkede hâkim olan komünist rejimin meşrulaştırılmasında da okuryazarlık ve kitap okuma alışkanlığı üzerinden propaganda mesajları verilmektedir. Kimi posterde komünist rejimden önce ve komünist rejimden sonra şeklinde bir alg1 oluşturulmakta, oluşturulan bu alg1 üzerinden komünist rejimden önce insanların belirli grupların etkisinde esaret altında yaşadığg iddia edilmekte, komünist rejimden sonra ise özgür bir yaşama kavuştuğu ileri sürülmektedir. Bu aşamada insanların kitap okuyarak Komünizm ideolojisinin öğretilerini öğrenen, haklarını savunan, mücadeleci bir hale geldikleri aktarılmaktadır. İnsanların haklarını savunmak için bir araya gelmesinde ve hatta devrime giden süreçte doğrudan kitapların etkili olduğuna yönelik mesaj verilmektedir.

Propaganda posterlerinde kitap okuyan insanlar, mutlu ve huzurlu bir yaşam içerisinde sunulmaktadır. İnsanların kitap okuyarak karanlıklardan uzaklaştığı ve aydınlık bir geleceğe kavuştukları iddia edilmektedir. Propaganda posterleri üzerinden okuryazarlık ve kitap okuma alışkanlığı teşvik edilmekle birlikte aynı zamanda insanların hangi kitapları okuması gerektiğiyle ilgili de yönlendirme yapılmaktadır. Posterlerdeki görsellerde ve yazılarda insanların okudukları kitapların Komünizm ideolojisiyle bağlantılı kitaplar olduğuna vurgu yapılmakta, bu şekilde insanların Komünizm ideolojisiyle ilişkili kitaplar okuması teşvik edilmektedir. Buna karşılık posterlerde Komünizm ideolojisi için tehdit oluşturabilecek olan kitaplara yönelik doğrudan olumsuz bir propagandaya girişilmemektedir. Sonuç olarak değerlendirildiğinde Lenin döneminde kullanılan propaganda posterlerinde hem okuryazarlı̆̆ın arttırılmasına ve kitap okuma alışkanlığının geliştirilmesine hem de Komünizm ideolojisinin meşrulaştırılmasına ve yüceltilmesine yönelik propagandanın yapılmaya çalışıldığı ortaya çıkmaktadır. Bu aşamada Komünizm ideolojisinin ve kitap okumanın birbirini tamamlayan bir yanı olduğuna yönelik kitleler nezdinde alg1 oluşturulmasının amaçlandığından söz 
edilebilmektedir. Çalışma kapsamında Lenin döneminde başlatılan okuryazarlık kampanyasında kitap okumasının teşvik edilmesine yönelik propaganda faaliyetleri, posterler özerlinde ortaya konulmaya çalışılmaktadır. Çalışma, Lenin dönemindeki Likbez kampanyasına 1şık tutması bakımından önem taşımaktadır. Buna karşılık çalışmanın yalnızca posterler üzerinden gerçekleştirilmesi ve 9 poster üzerinden elde edilen bulgular 1şı̆̆ında genellemelerde bulunulması çalışmanın temel sınırlılığını oluşturmaktadır. Bu açıdan gelecek çalışmaların Likbez kampanyasının dönemini farklı kitle iletişim araçları üzerinden, mevcut çalışmada elde edilen bulgularla karşılaştırmalı olarak incelemesinin konunun daha kapsamlı ortaya konulmasını sağlayacağı düşünülmektedir.

\section{Kaynakça}

Abendroth, M. (2014). Rebel Literacy: Cuba's national literacy campaign and critical global citizenship. The United States: Litwin Books.

Akinde, C. O., ve Omolewa, M. (1982). Background issues relating to the proposed Mass Literacy Campaign in Nigeria. International Review of Education, 28(1), 71-93. doi.org/10.1007/BF00597759

Aladağ, H. (2019). 1960'lar sonrası kütüphanecilik tarihimiz içinde bazı “Kütüphane Haftası” afişlerinin Roland Barthes'in göstergebilim metodu çerçevesinde analizi. Uluslararası Sosyal ve Eğitim Bilimleri Dergisi, 6(12), 133-147. https://doi.org/10.20860/ijoses.601210

Amare, G. (2006). An appraisal of the literacy campaign in Ethiopia during the military regime, 19741991. Journal of Ethiopian Studies, 39(1/2), 93-117.

Angus, E. (1980). The awakening of a people: Nicaragua's Literacy Campaign. Two Thirds, 2(3), 6-32.

Аракелова, М. П. (1994). Ликвидация неграмотности среди женщин в первой половине 20-х годов. Социологические исследования, (3), 75-78.

Arıca, F. A. (2019). Çin Halk Cumhuriyeti'nde Mao Zedong döneminde spor yayıncılığı üzerine inceleme. TRT Akademi, 4(8), 392-408.

Avc1, Ö. (2018). Propaganda çeşitleri. Karaca, M. ve Çakı, C. (Ed.) Illetişim ve propaganda içinde (s. 75-114). Konya: Eğitim Yayınevi.

Azab, S. A. (1985). The national adult literacy campaign in Iraq. Prospects, 15(3), 383-387. doi.org/10.1007/BF02196640

Васеха, М. В. (2018). "Крестьянка грамотная": ликбез в Западной Сибири и конструирование нового паттерна женского поведения в 1920-е годы. Вестник Новосибирского государственного университета. Серия: История. Филология, 17(5), 150-160.

Badiane, F. (1983). The literacy campaign in Senegal. Educafrica: Bulletin of the Unesco Regional Office for Education in Africa, 9, 192-198.

Barrington, L. (2005). Education, literacy, training, and propaganda in a Ghanaian border town. Ghana Studies, 8(1), 3-38.

Bradley, J. (2012). The St. Petersburg Literacy Committee and Russian education: government tutelage or public trust?. The Russian Review, 71(2), 267-294. doi.org/10.1111/j.14679434.2012.00653.x 
Braimoh, D. (1983). Communication strategies for effective literacy campaign in Nigeria. Nigeria Magazine, (145), 16-27.

Bredin, H. (1984). Roman Jakobson on metaphor and metonymy. Philosophy and Literature, 8(1), 89103.

Budd, A. M. (2018). Marksist teoriye bir katk1: Rusya'da devlet kapitalizmi teorisi. Enternasyonal Sosyalizm, 1(2), 74-83.

Сажина, А. И. (2012). Ликвидация неграмотности в Забайкалье в условиях ДВР (1920-1922 гг.). Вестник Забайкальского государственного университета, 10, 12-16.

Clark, C. E. (1995). Literacy and labour: The Russian literacy campaign within the trade unions, $1923-$ 27. Europe-Asia Studies, 47(8), 1327-1341.

Clark, C. E. (2000). Uprooting otherness: the literacy campaign in NEP-Era Russia. The United States: Susquehanna University Press.

Çakı, C. (2020). İnsan ticaretine karşı hazırlanan uluslararası kamu spotu reklamları: çocuk istismarı üzerine inceleme. Göç Araştırmaları Dergisi, 6(1), 60-91.

Çakı, C. ve Gülada, M. O. (2020). Komünizm ideolojisi altında Ermeni kadınların propaganda posterlerindeki temsili. Ermeni Araştırmaları, 66, 49-71.

Çalışkan, S., ve Doğan, D. K. (2020). İkinci Dünya Savaşı'nda Sovyetler Birliği'ndeki radyo yayınlarında propaganda şarkılarının kullanılması: "Kutsal Savaş" şarkısı üzerine inceleme. Eurasian Journal of Music And Dance, 16, 263-280. doi.org/10.31722/ejmd.757538

Çalışkan, S. (2020). Azerbaycan Sovyet Sosyalist Cumhuriyeti'nde propaganda posterleri üzerinden Stalin'in liderlik kültünün inşası. Gümüşhane Üniversitesi Illetişim Fakültesi Elektronik Dergisi, 8(2), 984-1010. doi.org/10.19145/e-gifder.717676

Dardour, M. (2000). The literacy campaign in rural Morocco: drawing some lessons. Prospects, 30(1), 125-142. doi.org/10.1007/BF02754052

Dündar, G. (2019). Mussolini İtalyası'nda spor yayıncılı̆̆ı. TRT Akademi, 4(8), 308-324.

Eklof, B. (1987). Russian literacy campaigns, 1861-1939. Arnove, R. F. and Graff. H. J. (Ed). In National Literacy Campaigns (p. 123-145). Boston, MA: Springer.

Erguig, R. (2017). The mosques-based literacy campaign in Morocco: A socio-cultural perspective. Studies in the Education of Adults, 49(1), 3-25. doi.org/10.1080/02660830.2017.1283755

Fischer-Jørgensen, E. (1997). Roman Jakobson and Denmark. Acta Linguistica Hafniensia, 29(1), 1328.

Fiske, J. (2017). İletişim çalışmalarına giriş̧. (S. İrvan, Çev.). 5. Bs. Ankara: Bilim ve Sanat Yayınları.

Gazi, M. A., Çakı, C., Gülada, M. O. ve Çakı, G. (2020). Çin Halk Cumhuriyeti Kültür Devrimi sürecinde okuma alışkanlığının propaganda posterlerinde sunumu. Türk Kütüphaneciliği, 34(3), 406-431.

Golobokova, Y. (2011). Literacy and democracy in Russia. ETC: A Review of General Semantics, 68(1), $50-55$.

Gülada, M. O. (2019). İkinci Dünya Savaşı'nda Sovyetler Birliği'nin casusluk karşıtı propagandasının posterlerdeki sunumu. Medeniyet ve Toplum Dergisi, 3(1), 49-68. 
Глущенко, И. В. (2015). Советский просветительский проект: ликвидация неграмотности среди взрослых в 1920-1930-е годы. Вопросы образования, 3, 246-282.

горюнова, а. г. (2012). советское государство и общественность в борьбе за грамотность женщин в 1920-е годы в регионе верхнего поволжья. ивановского государственного университета, 23-27.

Grainger, I. P. (1987). The literacy campaign in Zimbabwe. Journal of Social Development in Africa, 2(2), 49-58.

Guiraud, P. (2016). Göstergebilim. (M. Yalçın, Çev.). 3. Bs. Ankara: İmge Kitabevi.

Guroff, G., ve Starr, S. F. (1971). A note on urban şiteracy in Russia, 1890-1914. Jahrbücher für Geschichte Osteuropas, (H. 4), 520-531.

Iş1k, M. ve Karaca, M. (2019). Vichy Fransası'nda müttefik devletlerine karşı yürütülen propaganda faaliyeti. Anadolu Akademi Sosyal Bilimler Dergisi, 1(3), 43-62.

Hanemann, U. (2006). Nicaragua's literacy campaign. Paper commissioned for the EFA Global Monitoring Report, 1-13.

Herman, R. (2012). An army of educators: gender, revolution and the Cuban literacy campaign of 1961. Gender \& History, 24(1), 93-111. doi.org/10.1111/j.1468-0424.2011.01670.x

Hobbs, R., and McGee, S. (2014). Teaching about propaganda: an examination of the historical roots of media literacy. Journal of Media Literacy Education, 6(2), 56-67.

Hobbs, R., Seyferth-Zapf, C., and Grafe, S. (2018). Using virtual exchange to advance media literacy competencies through analysis of contemporary propaganda. Journal of Media Literacy Education, 10(2), 152-168. doi.org/10.23860/JMLE-2018-10-2-9

Kalkina, V. (2020). Between humour and public commentary: digital re-appropriation of the Soviet propaganda posters as internet memes. Journal of Creative Communications, 15(2) 131-146. doi.org/10.1177/0973258619893780

Karabulut, F. (2009). İktidar ve meşrulaştırma mücadelesinin odağı orta Asya: Sovyetlerin dil ve eğitim politikaları. Bilig Dergisi, 50, 64-95.

Karaca, M. (2018). İtalyan Sosyal Cumhuriyeti'nin iş gücü elde etmek amaciyla yürüttüğü propaganda faaliyetleri. EUropean Journal of Managerial Research (EUJMR), 2(2), 119-136.

Kefeli, A. N. (2014). Becoming Muslim in imperial Russia: Conversion, apostasy, and literacy. New York: Cornell University Press.

Keskin Yılmaz, Y., Çakı, C ve Kazaz, A. (2020). Nazi Almanya'sı döneminde Nazizm ideolojisindeki antisemitist propaganda mitlerinin eğitime yansıması. Selçuk İletişim, 13(3), 1081-1113.

Kızılcı, S., Kavuran, T. (2019). İkinci Dünya Savaşı'nda Japonya karşıtı ABD propaganda posterlerinin korku çekiciliği bağlamında incelenmesi. Anadolu Akademi Sosyal Bilimler Dergisi, 1(3), 6378.

Kisel, M. (2008). Literacy and literary mastery in early Soviet Russia: the Case of Yuri Olesha's "Envy". Ulbandus Review, 11, 23-45.

Klarin, V. (1970). Lenin and Krupskaya in the struggle for public education. Soviet Education, 12(12), 51-64.

Korolev, F. F. (1970). Lenin and public education. Prospects in Education, 1(2), 45-50. 
Koutaissoff, E. (1951). Literacy and the place of Russian in the non-Slav republics of the USSR. EuropeAsia Studies, 3(2), 113-130.

Kraevskii, V. V. (1987). The Soviet Union's experience in the elimination of adult literacy. Convergence, 20(2), 20-25.

Kučera, H. (1983). Roman Jakobson. Language, 59(4), 871-883.

Lapko, A. F., ve Lyusternik, L. A. (1970). Lenin, science and education. Russian Mathematical Surveys, 25(2), 13-76.

Лебедева, Л. В. (2012). Проблемы ликвидации неграмотности крестьян в первое десятилетие советской власти. Известия Пензенского государственного педагогического университета им. ВГ Белинского, (27), 776-778.

Leiner, M. (1987). The 1961 national Cuban literacy campaign. Arnove, R. F. and Graff, H. J. (Ed.). In National Literacy Campaigns (p. 173-196). Boston, MA: Springer.

Lilge, F. (1968). Lenin and the politics of education. Slavic Review, 27(2), 230-257.

Липатова, Н. В. (2012). Политический ликбез как пропуск в ряды кадрового резерва советского руководства на местах в 20-е гг. Хх в. Известия Иркутского государственного университета. Серия: Политология. Религиоведение, (2-2), 85-91.

Lucas, C. J. (1981). Arab illiteracy and the mass literacy campaign in Iraq. Comparative Education Review, 25(1), 74-84.

Maharramova C. N., ve Şimşek, A. (2017). Sovyetler Birliği döneminde Rusya'da okutulan tarih ders kitaplarında Türk imajı. CTAD: Cumhuriyet Tarihi Araştırmaları Dergisi, 13(26), 37-66.

Mammo, G. (1982). The national literacy campaign in Ethiopia. Prospects, 12(2), 193-199.

Mažeikienè, N., ve Juraite, K. (2014). Propaganda, critical media literacy and participation: Tracing memories of the Soviet media. CM-Časopis Za Upravljanje Komuniciranjem, 9(30), 79-104.

McKay, V. (2018). Through the eye of a fly: action research as a support for the South African national literacy campaign. Systemic Practice and Action Research, 31(4), 375-393. doi.org/10.1007/s11213-017-9431-x

Mironov, B. N. (1986). Literacy in Russia, 1797-1917: obtaining new historical information through the application of retrospective prediction methods. Soviet Studies in History, 25(3), 89-117. doi.org/10.2753/RSH1061-1983250389

Mironov, B. N. (1991). The development of literacy in Russia and the USSR from the tenth to the twentieth Centuries. History of Education Quarterly, 31(2), 229-252. Doi: 10.2307/368437

Mohanty, A. K. (2005). Paradigms of learning: the total literacy campaign in India. Contemporary Education Dialogue, 2(2), 249-252. doi.org/10.1177/097318490500200207

Monoszon, E. I. (1981). V I Lenin and methods of communist education. Soviet Education, 23(4), 3552. doi.org/10.2753/RES1060-9393230435

Mpofu, S. T. (1997). The fallacies of literacy campaigns: reflections on the Zimbabwe national literacy campaign. Zimbabwe Journal of Educational Research, 9(1), 18-43.

Mujica, R. J. (1981). Some recollections of my experiences in the Cuban Literacy Campaign. Journal of Reading, 25(3), 222-225. 
Natolochnaya, O. V., Bulgarova, B. A., and Bragina, M. A. (2018). The struggle for literacy in the Russian troops in the late 1850s-Early 1860s. Былые годы. Российский исторический журнал, 47, 225-231.

Nazarova, L. K. (1988). An Outline of the History of the Methods of Teaching Literacy in Soviet Russia, 1917-1947. John A. (Ed.). Downing. in Advances in Psychology (V. 49, p. 37-65). Amsterdam: North-Holland.

Omolewa, M. (2008). Programmed for failure? The colonial factor in the mass literacy campaign in Nigeria, 1946-1956. Paedagogica Historica, 44(1-2), 107-121.

Ortega, D., and Rodríguez, F. (2008). Freed from illiteracy? A closer look at Venezuela's Misión Robinson literacy campaign. Economic Development and Cultural Change, 57(1), 1-30.

Özdemir, B. (2016). Rusya'nın kırsal kesiminde Komünist Gençler Birliği'nin (Komsomol) kuruluşu ve Sovyet iktidarının güçlenmesindeki rolü: 1918-39. Marmara Türkiyat Araştırmaları Dergisi, 3(1), 19-30. DOI: 10.16985/MTAD.2016126863

Özdemir, B. (2018). Sovyetler Birliği'nde komünist ideolojinin eğitime yansımaları: 1920'li ve 1930'lu y1llar. Çanakkale Onsekiz Mart Üniversitesi Uluslararası Sosyal Bilimler Dergisi, 3(1), 103111.

Павлова, Л. В. (2014). Общество «Долой неграмотность» и его роль в ликвидации неграмотности в Оренбуржье в 20-30-е гг. ХХ в. Общество: философия, история, культура, (1), 40-44.

Paul, N. L. (2010). A warlord's wisdom: literacy and propaganda at the time of the First Crusade. Speculum, 85(3), 534-566.

Петрова, Я. И. (2007). Ликбез как социальный проект (на материалах Самарской губернии, 19201930-е годы). Журнал исследований социальной политики, 5(4), 519-540.

Prieto, A. (1981). Cuba's national literacy campaign. Journal of Reading, 25(3), 215-221.

Rao, N. (1999). Cycling into the future: a report on women's participation in a literacy campaign in Tamil Nadu, India. Gender, Technology and Development, 3(3), 457-474.

Ravkin, Z. (1964). Struggle for the Leninist Style of Work in the People's Commissariat of Education. Soviet Education, 6(11), 44-54.

Redavantgarde (2020). Sovyetler Birliği propaganda posterleri. Erişim adresi http:// redavantgarde. $\mathrm{com} / \mathrm{en} /$ collection /show -collection/ ?themeId= 53

Rifat, M. (2013). Açıklamalı göstergebilim sözlüğ̈̈: kavramlar, yöntemler, kuramcılar, okullar. İstanbul: Türkiye İş Bankası Kültür Yayınları.

Riordan, J. (1989). The Komsomol. Riordan, J. (Ed.). In Soviet youth culture (p. 16-44). London: Palgrave Macmillan.

Ross, L. W. (1960). Some aspects of Soviet education. Journal of Teacher Education, 11(4), 539-552.

Salma, A. N. (2019). Defining digital literacy in the age of computational propaganda and hate spin politics. KnE Social Sciences, 323-338. DOI: 10.18502/kss.v3i20.4945

Serra, A. (2001). The literacy campaign in the Cuban Revolution and the transformation of identity in the liminal space of the Sierra. Journal of Latin American Cultural Studies, 10(1), 131-141. doi.org/10.1080/13569320020030097

Soundarapandian, M. (2000). Literacy campaign in India. India: Discovery Publishing House. 
Stevens, C. B. (1980). Belgorod: Notes on Literacy and Language in the Seventeenth-Century Russian Army. Russian History, 7(1), 113-124.

Şahan, S. (2020). Sovyetler Birliği'nde Batı Blok'unun radyo yayınlarının karikatürler üzerinden eleştirisi. TRT Akademi, 5(9), 270-291.

Unsicker, J. (1987). Tanzania's literacy campaign in historical-structural perspective. Arnove, R. F. and Graff, H. J. (Ed.). In National Literacy Campaigns (p. 219-244). Boston, MA: Springer.

Wade, R. A. (2006). The october revolution, the Constituent Assembly, and the end of the Russian Revolution. Thatcher, I. D. (Ed.). In Reinterpreting Revolutionary Russia (p. 72-85). London: Palgrave Macmillan.

Yılmaz, M. B. (2020). İkinci Dünya Savaşı'nda Japon medyasının ABD'ye yönelik faaliyetleri: Tokyo Rose Radyo yayınları üzerine inceleme. İnsan ve Toplum Bilimleri Araştırmaları Dergisi, 9(1), 541-563. https://doi.org/10.15869/itobiad.657946

Yılmaz, M. B., Çakı, C. ve Gazi, M. A. (2020). Nazi Almanyası işgalindeki Sırbistan'da antisemitist propaganda faaliyetleri. Anemon Muşs Alparslan Üniversitesi Sosyal Bilimler Dergisi, 8(2), 441-450.

Zepper, J. T. (1965). NK Krupskaya on complex themes in Soviet education. Comparative Education Review, 9(1), 33-37.

Zimianin, M. (1985). Following Leninist principles for the development of public education. Soviet Education, 28(1), 43-74.

Zitser, E. A. (2018). Raphael Lemkin and the Soviet propaganda poster collection at Duke University Library. Slavic \& East European Information Resources, 19(3-4), 242-262. doi.org/10.1080/15228886.2018.1538863

\section{Summary}

Vladimir Lenin, the leader of the October Revolution and the intellectual leader of the MarxistLeninist ideology, made important attempts to increase literacy in Russia during his rule. At this stage, people were encouraged to learn to read and write and read books with the literacy campaign launched in the country. The importance of people who knew to read and write was emphasized and people who read books were presented to the masses as idealized citizens in the propaganda posters prepared in the propaganda activities carried out in the country. Despite the fact that Lenin's literacy campaign coincided with the years of the Russian Civil War (19171922), the campaign continued and tried to increase the rate of literacy in Russia and made people gain the habit of reading books. In this study, it was examined which messages were given in the propaganda activities carried out to encourage the masses to read books in the literacy campaign initiated in the Lenin period, especially on propaganda posters, and how propaganda was used in the reading habit of the masses.

Based on the findings obtained within the scope of the study, the following questions were tried to answer;

- What messages were given to encourage literacy learning of the masses?

- What was the role of the Communism ideology in the reading habit of the masses?

- How were people reading books presented on posters?

- Which visual and written codes were used to encourage reading books? 
The study was important in terms of providing information about the educational policy of the Lenin period, revealing the role of the discourses of the Communist ideology in the literacy campaign in Russia and reflecting the discourses of the Communist regime in Russia after the October Revolution to encourage reading books. Based on the findings obtained in the study, it was aimed to explain what role ideological discourses could have on the literacy campaign and the promotion of book reading. In the study, all propaganda posters that encouraged reading in the literacy campaign initiated under the leadership of Lenin after the 1917 October Revolution constituted the universe of the study. As a result of the comprehensive examination carried out within the scope of the study, 42 propaganda posters on the subject prepared during the Lenin period were found. 9 propaganda posters that were determined by using a quota sample and thought to reflect the universe in the best way in 42 propaganda posters were analyzed as samples of the study.

The semiotic analysis method, which is among the qualitative research methods, was used to examine the propaganda posters determined within the scope of the study. In the posters examined in the study, it was revealed that various propaganda posters were prepared based on different messages aimed at increasing literacy and making reading habits in Russia. At this stage, the direct effect of Communism ideology on propaganda posters was reflected. The perception that literacy and reading books were directly related to the Communism ideology was tried to be form and the message was given that people could learn the teachings of the Communism ideology and have the idealized lifestyle of the Communism ideology through propaganda posters. Based on the metaphors used in the posters, it was stated that the people who read books were people living under the Communist regime. In this way, the emphasis on Communist rule and the impact of Communist rule on people's lives was directly reflected in posters. People were tried to form a perception that the Communism ideology was effective in reading books. On the other hand, propaganda messages were given through literacy and the habit of reading books in the legitimation of the Communist regime that prevailed in the country. In some posters, a perception was formed as before and after the Communist regime and it was claimed that people lived in captivity under the influence of certain groups before the Communist regime and they had a free life after the Communist regime, based on this perception. At this stage, it was reported that people learned the teachings of the Communism ideology, defended their rights and became combative by reading books.

People who read books were presented in a happy and peaceful life on propaganda posters. It was claimed that people got away from the darkness and reach a bright future by reading books. Literacy and reading habits were encouraged, as well as guidance on which books people should read through propaganda posters. In the visuals and writings in the posters, it was emphasized that the books people read were related to the Communism ideology, it was encouraged that people read books related to the Communism ideology. On the other hand, there was no direct negative propaganda against the books that may pose a threat to the Communism ideology. As a result, it can be seen that propaganda posters used during the Lenin period were attempted to increase literacy and to develop the habit of reading books and to legitimize and glorify the Communism ideology. At this stage, it can be said that it was aimed to form a perception among the masses that the Communism ideology and reading books complement each other. Propaganda activities aimed at encouraging reading books in the 
literacy campaign initiated in the Lenin period were tried to be presented through posters within the scope of the study. The study is important in that it gives information about the Likbez practice in the Lenin period. On the other hand, the main limitation of the study is that the study was conducted only on posters and generalizations were made in the light of the findings obtained from 9 posters. In this respect, it is thought that future studies will examine the Likbez period through different mass media, in comparison with the findings obtained in the present study, will provide a more comprehensive presentation of the subject. 